\title{
WILEY-VCH
}

DOI: 10.1002/ ((please add manuscript number))

Article type: Review

\section{Trends in aluminium-based intercalation batteries}

Filip Ambroz, Thomas J. Macdonald, and Thomas Nann*

Mr. F. Ambroz, Dr. T. J. Macdonald

Department of Chemistry, University College London, London, UK

Prof. T. Nann

The MacDiarmid Institute for Advanced Materials and Nanotechnology

Victoria University of Wellington, Wellington, 6041, New Zealand

E-mail: thomas.nann@vuw.ac.nz

Keywords: aluminium, batteries, energy storage, intercalations, layered compounds

Over the last decade, optimizing energy storage has become significantly important in the field of energy conversion and sustainability. As a result of immense progress in the field, costeffective and high performance batteries are imperative to meeting the future demand of sustainability. Currently, the best performing batteries are lithium-ion based, but limited lithium (Li) resources make research into alternatives essential. In recent years, the performance of aluminium-ion batteries has improved remarkably in all battery-relevant metrics, which renders them a promising alternative. Compared with monovalent Li-ion batteries, aluminium ( $\mathrm{Al})$ cations can carry three positive charges, which could result in higher energy densities. This review describes recent developments in Al-based cathode materials. The major goal of this review is to highlight strengths and weaknesses of various different approaches and provide guidelines for future research.

\section{Introduction}

Currently, the most widely used commercial batteries in portable devices are lithium-ion batteries (LIB). They were introduced by Sony in 1990 and comprised of two intercalated electrodes i.e. carbon anode and $\mathrm{LiCoO}_{2}$ cathode, which are separated by an organic electrolyte 


\section{WILEY-VCH}

solution. Nowadays, LIBs are well established and their performance has improved significantly over the past 10 years, ${ }^{[1-3]}$ however their limitations are often overlooked. Given the growth of the electric vehicle market together with the increasing demand of portable devices, makes progress in renewable energy generation and storage essential in the modern world. Interestingly, lithium (Li) is the least abundant metal of other promising candidates for metal electrodes (Table 1), and this suggests that LIBs are not the solution for the future of sustainable energy storage. Moreover, they possess other limitations including possible thermal runaway and ultimately combustion, high fabrication cost, failure when fully discharged and limited energy density. In a global economy that is shifting towards renewable energy, large scale and portable energy storage becomes increasingly more important. Therefore, continued research into high-performing alternatives, which will meet the increased demand is imperative. A common way of evaluating potential alternatives for Li-based batteries involves calculating the theoretical specific capacity of potential candidates and comparing these results with other figures of merit. This reasoning leads to the conclusion that metals in the upper left corner of the periodic table are more interesting than the others. Table 1 shows these calculations together with some other parameters for common metal anodes.

\section{[Table 1]}

A second important parameter when searching for potential battery materials is the oxidation potential of the anode, where lower (less noble) is better. Comparing these parameters for the metals listed in Table 1 shows immediately that $\mathrm{Li}$ is one of the most promising candidates, but rare. The second most promising metal is aluminium $(\mathrm{Al})$, which has a relatively high standard oxidation potential. Heavier metals and those in higher groups show much worse performance indicators. Nevertheless, this method of evaluation has to be considered with 


\section{WILEY-VCH}

caution, because it is based on numerous assumptions. Such as, that the anode is oxidized during the charging/discharging process, which is not true for many practical systems.

The literature on non-Li based intercalation batteries is clearly dominated by sodium $(\mathrm{Na}),{ }^{[4,5]}$ magnesium $(\mathrm{Mg})^{[6,7]}$ and $\mathrm{Al}^{[8]}$ systems that are all more abundant natural elements than Li. There are few examples of potassium $(\mathrm{K})^{[9]}$ and $(\mathrm{Ca}),{ }^{[10]}$ which coincides clearly with the trend observed in Table 1 (as mentioned above, low performing "candidates" have been omitted in this table). Great efforts are aimed at these alternatives to improve capacity, power and cycles. Comparing Na-ion with Li-ion batteries, the common feature is a monovalent ion that can be inserted/extracted into/from the electrode material. Here, only one charge transfer takes place in contrast to $\mathrm{Mg}$-ion, $\mathrm{Ca}$-ion or $\mathrm{Al}$-ion where two and three charges are involved in redox reactions respectively. As a result of multi-electron reactions, higher specific capacity and energy density may be obtained. A key issue in order for multivalent ion insertion to be feasible is the electrode material that has to allow ion mobility.

In this review, electrode materials for Al-ion batteries, namely different cathodes are discussed. Furthermore, their performance is compared highlighting drawbacks and advantages of every material.

\section{Aluminium-ion batteries}

Aluminium is the third most abundant element in the earth's crust ${ }^{[11]}$ and the most abundant element among the metals. In combination with three-electron redox properties $\left(\mathrm{Al}^{3+} / \mathrm{Al}\right)$ that leads to high capacity and in addition to low cost, low flammability, easy handling and low reactivity, Al-based batteries could offer an alternative to LIB systems. As indicated in table 1, the capacity of $\mathrm{Al}$ is very attractive. Al has a high specific capacity per mass unit $(2980 \mathrm{Ah} / \mathrm{kg})$ and the highest capacity per unit of volume $(8046 \mathrm{Ah} / \mathrm{L})$. Together with its relatively low atomic weight makes $\mathrm{Al}$ a promising candidate for anode material. The first battery system where $\mathrm{Al}$ was employed as anode ("the Buff cell”) dates back to year 1857. Approximately 40 years later an amalgamated alloy with zinc was used together with a carbon cathode and in 1948 heavy- 


\section{WILEY-VCH}

duty chlorine-depolarized $\mathrm{Al}$ batteries were reported. ${ }^{[12]}$ The open circuit voltage of the latter battery systems was very high i.e. $2.45 \mathrm{~V}$. Therefore, a battery cell utilizing Al could be very appealing, and several patents have also been issued for these systems. ${ }^{[13,14]}$ Sargent ${ }^{[15]}$ proposed in 1951 a voltaic cell having $\mathrm{Al}$ as the negative electrode (anode) and carbon as the positive electrode (cathode) while the electrolyte was an aqueous caustic alkaline solution containing dissolved zinc oxide. Additional improvements were made by Ruben ${ }^{[16]}$ who discovered a cell comprised of $\mathrm{Al}$ anode and a depolarizer of manganese oxide $\left(\mathrm{MnO}_{2}\right)$ with an electrolyte of manganese chloride. Afterwards, many other discoveries emerged. ${ }^{[17-19]}$ Despite these discoveries, none of them were commercialized because $\mathrm{Al}$ batteries have certain limitations when used with aqueous electrolytes (primary batteries). One of them is a protective oxide film that forms on the $\mathrm{Al}$ surface. This results in a decrease in cell efficiency, lower reversible electrode potential and time lag before the cell reaches its maximum operating voltage. ${ }^{[11,12]}$ Another limitation includes water splitting within the aqueous electrolyte. This is a consequence of the standard electrode potential of $\mathrm{Al}(-1.662 \mathrm{~V})$ and the intrinsic hydrogen generation introduces certain restrictions and reduces the efficiency of anode. ${ }^{[1,20]}$ To overcome these limitations, non-aqueous electrolytes (secondary batteries) have to be used in Al-ion batteries. In order for a non-aqueous electrolyte to be appealing in Al-ion battery system, it has to possess certain characteristics. For instance, efficiently spread through the pores of the cathode (effect on electrode kinetics), its electrical conductivity has to be high and it has to be electrochemically stable. ${ }^{[11]}$ The most widespread non-aqueous room-temperature electrolytes in Al-ion batteries are aluminium chloride $\left(\mathrm{AlCl}_{3}\right)$ containing imidazolium based ionic liquids. ${ }^{[8,11,20-26]}$ Imidazolium iodides are frequently used in dye-sensitized solar cells (DSSCs) as an additive to improve the performance of the common iodide/triiodide $\left(\mathrm{I}^{-} / \mathrm{I}_{3}^{-}\right)$electrolyte system. ${ }^{[27-31]}$ This improvement in performance is based on the imidazolium cation and its electrostatic interaction between diffusion coefficients of $\mathrm{I}^{-}$and $\mathrm{I}_{3}^{-}$and current density values. ${ }^{[32]}$ 


\section{WILEY-VCH}

The Al-ion battery system operates on the principle of an intercalation mechanism, namely on reversible insertion of ions/molecules into the cathode material which is illustrated in this review. For this process, energy that comes from redox reactions is essential as guest ions/molecules expand the van der Waals gap between sheets in the material. An intercalation battery works via deposition and dissolution of $\mathrm{Al}$ i.e. the anode and intercalation/extraction of anions at the cathode through the conductive electrolyte. Anode and cathode systems could then be analysed by XRD (X-ray diffraction), XPS (X-ray photoelectron spectroscopy), SEM (scanning electron microscopy) and TEM (transmission electron microscopy).

Another factor that is of significance in a battery system are the charge and discharge rates. Preferably these rates should be as high as possible. Since intercalation batteries work on ions insertion/extraction, the radius of these ions could have an impact on the rate of charging and discharging. Herein the $\mathrm{Al}^{3+}$ cation $(53.5 \mathrm{pm})$ has a smaller radius than $\mathrm{Li}^{+}$cation $(76 \mathrm{pm})$ indicating itself as a promising candidate for the intercalation mechanism. ${ }^{[33]}$ The electrode cell configuration used for the majority of the cathode materials described in this review is illustrated in Figure 1.

\section{[Figure 1]}

\section{Cathode materials}

\subsection{Graphite}

Graphite, as one of the allotropes of carbon, occurs in abundance in many places around the world. As a result, the cost of raw graphite remains low. Therefore, battery systems implementing a graphite cathode together with Al anode could be appealing for low cost systems.

As reported by Sun et al. ${ }^{[21]}$ a battery with an $\mathrm{Al}$ anode, graphite cathode and electrolyte that is a mixture of $\mathrm{AlCl}_{3}$ and 1-ethyl-3-methylimidazolium chloride operates on a system of 


\section{WILEY-VCH}

multi-coordination ion/single ion intercalation/deintercalation. During the discharge, $\mathrm{Al}$ is oxidized to form $\mathrm{Al}^{3+}$ ions that together with the coordination anions from the electrolyte $\left[\mathrm{Al}_{\mathrm{a}} \mathrm{Cl}_{\mathrm{b}}\right]^{-}$(i.e. $\mathrm{AlCl}_{4}^{-}$and $\mathrm{Al}_{2} \mathrm{Cl}_{7}^{-}$) move to the cathode where they concurrently intercalate into the material. In the course of the charging process, the redox reactions are reversed meaning no chemical bonds are formed between the ions and the cathode. Therefore adjacent graphite layers provide a large space for ions that after being intercalated get formed to $\mathrm{Al}_{\mathrm{x}} \mathrm{Cl}_{\mathrm{y}} \cdot{ }^{[21]}$

The redox reactions that take place during the charging process are: ${ }^{[21]}$

anode: $\quad \mathrm{Al}^{3+}+3 \mathrm{e}^{-} \rightarrow \mathrm{Al}$

cathode: $\quad \mathrm{Al}_{\mathrm{x}} \mathrm{Cl}_{\mathrm{y}}-\mathrm{e}^{-} \rightarrow \mathrm{Al}^{3+}+\left[\mathrm{Al}_{\mathrm{a}} \mathrm{Cl}_{\mathrm{b}}\right]^{-}$

and during the discharging process:

anode: $\quad \mathrm{Al}-3 \mathrm{e}^{-} \rightarrow \mathrm{Al}^{3+}$

cathode: $\quad \mathrm{Al}^{3+}+\left[\mathrm{Al}_{\mathrm{a}} \mathrm{Cl}_{\mathrm{b}}\right]^{-}+\mathrm{e}^{-} \rightarrow \mathrm{Al}_{\mathrm{x}} \mathrm{Cl}_{\mathrm{y}}$

The structure of graphite consists of adjacent layers of carbon atoms which are separated from neighbouring planes by weak forces. Between these interlayer sheets of graphite, redox reactions occur during the process of charging/discharging resulting in unchanged morphology of the cathode surface as it was not involved during these two processes. Meanwhile, the volume of the cathode becomes larger since the sheets of carbon atoms expand after being charged leading to more inserted ions and a larger surface area that eventually has an effect on better mass transfer (contact) of the cathode and the ionic electrolyte. At the same time, the structure of graphite as a result of good crystallization stays stable which can contribute to a 


\section{WILEY-VCH}

better cycle life of the battery system. Since the graphite structure remains unchanged, no chemical bonds are formed between the graphite and the intercalated ions, respectively. ${ }^{[21]}$

In such systems, ${ }^{[21]}$ during the initial few cycles the discharge capacity moderately increased as a result of graphite volume adjustments, side reactions and enlarged surface area of the cathode. Thereafter the capacity remained relatively constant leading to a discharge capacity of approx. $70 \mathrm{mAh} \mathrm{g}{ }^{-1}$ over 100 cycles at $100 \mathrm{~mA} \mathrm{~g}^{-1}$ current density. ${ }^{[21]}$ In the beginning coulombic efficiency was slightly reduced however, after several cycles it increased up to $100 \%$. Different discharge capacities could be obtained by manipulating with current densities. For instance, higher capacity $\left(85 \mathrm{mAh} \mathrm{g}^{-1}\right)$ could be obtained with $50 \mathrm{~mA} \mathrm{~g}^{-1}$ current density over 50 cycles. ${ }^{[21]}$ The discharge cut-off voltage of the battery system is $0.4 \mathrm{~V}$ and the average voltage plateau is cca. $1.8 \mathrm{~V}$. This value is comparing to other Al-ion battery systems discussed herein exceptionally high. Together with great coulombic efficiency the battery possesses two promising characteristics. However, the discharge capacity and cycle life together with average current density are still not enough high for commercial applications of a battery system.

\subsection{Pyrolytic graphite}

Naturally occurring graphite possesses an imperfect structure as a result of defects and inclusions. The structure could be modified with various procedures to obtain a better grade of 3-D ordering. One of them that is the most widely used is known as pyrolysis.

A battery with pyrolytic graphite (PG) which has an open, three-dimensionally-bound structure as a cathode instead of natural graphite ${ }^{[21]}$ has a greater structural integrity as a result of covalent bonding between adjacent graphene sheets. ${ }^{[8]}$ This characteristic does not lead to material expansion during charging that could have effect on cathode disintegration. Rechargeable $\mathrm{Al} / \mathrm{PG}$ cell with ionic liquid electrolyte, namely $\mathrm{AlCl}_{3} / 1$-ethyl-3-methylimidazolium chloride works via ion intercalation/deintercalation. During discharging redox reaction that takes place on the anode can be written as: ${ }^{[8]}$ 
$\mathrm{Al}+7 \mathrm{AlCl}_{4}^{-} \rightarrow 4 \mathrm{Al}_{2} \mathrm{Cl}_{7}^{-}+3 \mathrm{e}^{-}$

Herein, atoms of $\mathrm{Al}$ (anode) and ions of $\mathrm{AlCl}_{4}^{-}$get transformed into $\mathrm{Al}_{2} \mathrm{Cl}_{7}^{-}$. The side products of this redox reaction are $3 \mathrm{e}^{-}$. One of the biggest advantages of an Al-ion battery system are these 3 electrons that form and could result in more charge transfer leading to higher gravimetric and volumetric capacity. This is a distinct advantage when compared to a one-charge transfer from Li-ion, ${ }^{[34]} \mathrm{Na-ion}{ }^{[4]}$ and $\mathrm{K}$-ion ${ }^{[35]}$ battery systems as well as two charge transfer in Caion $^{[10]}$ and Mg-ion ${ }^{[36]}$ battery system.

The redox reaction that can simultaneously occur on the cathode is as follows: ${ }^{[8]}$

$\mathrm{C}_{\mathrm{n}}\left[\mathrm{AlCl}_{4}\right]+\mathrm{e}^{-} \rightarrow \mathrm{C}_{\mathrm{n}}+\mathrm{AlCl}_{4}^{-}$

Herein, $n$ is the molar ratio of carbon atoms against $\mathrm{AlCl}_{4}^{-}$ions in the graphene layers. In this redox reaction $\mathrm{AlCl}_{4}^{-}$ions are de-intercalated from graphite. During charging the redox reactions are reversed, namely for the anode:

$4 \mathrm{Al}_{2} \mathrm{Cl}_{7}^{-}+3 \mathrm{e}^{-} \rightarrow \mathrm{Al}+7 \mathrm{AlCl}_{4}^{-}$

and for the cathode:

$\mathrm{C}_{\mathrm{n}}+\mathrm{AlCl}_{4}^{-} \rightarrow \mathrm{C}_{\mathrm{n}}\left[\mathrm{AlCl}_{4}\right]+\mathrm{e}^{-}$

The anions $\mathrm{AlCl}_{4}^{-}$and $\mathrm{Al}_{2} \mathrm{Cl}_{7}^{-}$that are essential for the above described process come from the electrolyte. Schematic operation scheme of the pre-described battery system in the course of battery discharge could be seen in Figure 2. 


\section{WILEY-VCH}

\section{[Figure 2]}

Due to high reversibility of anion intercalation/deintercalation, over 200 charge-discharge cycles were achieved at a current density of $66 \mathrm{~mA} \mathrm{~g} \mathrm{~g}^{-1} \cdot{ }^{[8]}$ Higher current densities resulted in a loss of specific capacity, which is at the rate of $66 \mathrm{~mA} \mathrm{~g}^{-1}$ limited to around $65 \mathrm{mAh} \mathrm{g}^{-1}$. This barrier is related to slow anion diffusion in the sheets of pyrolytic graphite at higher charge/discharge rates.

Coulombic efficiency at the pre described rate is very high with approx. $98 \%$. In order to preserve such a high efficiency, the charge cut-off voltage is set to $2.45 \mathrm{~V}$. That is higher than in the system with natural graphite as cathode. ${ }^{[21]}$ Therefore the average voltage plateau is remarkably high as well in the ranges of $2.25-2.0 \mathrm{~V} \cdot{ }^{[8]}$ This is the highest average voltage plateaus ever been reported for an Al-ion battery.

\subsection{Graphitic foam}

In order to facilitate ion intercalation/deintercalation the cathode material has to possess microscopic spaces within its structure. These spaces should therein prevent energetic barriers for intercalation/deintercalation of chloroaluminate anions that are fairly large.

Dai and co-workers ${ }^{[8]}$ made this kind of material by chemical vapour deposition (CVD) on a nickel foam template. A graphitic foam with an open frame structure which can result in reduced diffusion length for intercalating anions can be seen in Figure 3.

\section{[Figure 3]}

Therefore, charge and discharge current densities are extraordinary high with a graphitic foam cathode, reaching values up to $5000 \mathrm{~mA} \mathrm{~g}^{-1}$ (75 C). These values are the highest ever reported for an Al-ion battery system. Together with outstanding current density Al/graphitic foam cell 


\section{WILEY-VCH}

possesses high average voltage plateau (around $2 \mathrm{~V}$ ), wherein discharge capacity is relatively low $\left(60 \mathrm{mAh} \mathrm{g}^{-1}\right)$. Cycling stability of the graphitic foam is impressive as well with over 7500 cycles achieved at Coulombic efficiency of approx. $97 \%$ at $4000 \mathrm{~mA} \mathrm{~g}^{-1}{ }^{([8])}$ This is the highest stability of any ultrafast battery system yet to be published. Moreover, the pre described battery cell preserved discharge capacity over a range of charge-discharge rates $\left(1000-6000 \mathrm{~m} \mathrm{~A} \mathrm{~g}^{-1}\right)$ with very attractive stability and capacity retention. When it is charged at a rate of $5000 \mathrm{~mA} \mathrm{~g}^{-}$

${ }^{1}$ it can be slowly discharged down to $100 \mathrm{~mA} \mathrm{~g}^{-1}$ (approx. $34 \mathrm{~min}$ ) while preserving its discharge capacity $\left(60 \mathrm{mAh} \mathrm{g}^{-1}\right)$ and Coulombic efficiency in the ranges of $85-99 \% .{ }^{[8]}$ The Al/graphitic foam cell operates on the same way as the batteries mentioned above with graphite or pyrolytic graphite cathode using the same electrolyte.

Despite of relatively low voltage profile and discharge capacity (comparing to other intercalation based battery systems ${ }^{[37,38]}$ ) this battery might be very attractive in many practical applications as a result of very high charging rate and stable variable discharging. It also does not present any safety hazard and has ability to be cost effective.

\subsection{Graphene mesh network}

In relation to the promising results achieved with graphitic foam, Liu and co-workers ${ }^{[39]}$ designed 3D graphene mesh network (GMN) that can be utilized as cathode in the same battery cell configuration.

The cathode material was fabricated implementing folded Ni meshes followed by CVD method and eventually the initial meshes removal. ${ }^{[39]}$ Figure 4 illustrates GMN that was obtained. Perforated mesh-like structure with hollow tubes in cross-sectional view can be seen under a. After folding 4 layers of meshes under pressure, a 3D structure resulted with the thickness of $185 \mu \mathrm{m}$ (b).

\section{[Figure 4]}




\section{WILEY-VCH}

One of the main advantages of this material is the fabrication process. With this process, the structure parameters can be well controlled meaning certain characteristics e.g. density, electrical and thermal conductivity are improved comparing to graphitic foam. Nevertheless, the discharge capacity $\left(57 \mathrm{mAh} \mathrm{g}^{-1}\right)$ is roughly the same at much lower current density $(2400$ $\mathrm{mA} \mathrm{g}^{-1}$ ) and considerably less cycle numbers (200). ${ }^{[39]}$ However, comparing to other cathode materials discussed herein the charge/discharge rate is still outstandingly high with constant coulombic efficiency close to $100 \%$. Such high values are related to the structure of GMN where ions can move faster and more efficient. Considering the commercial value of the battery, its discharge capacity is too low to be appealing. In spite of that, as the volumetric density (15.7 $\left.\mathrm{mg} \mathrm{cm}{ }^{-3}\right)$ is almost 6 times higher from the graphitic foam $\left(2.7 \mathrm{mg} \mathrm{cm}^{-3}\right)$, volumetric capacity can be improved in that regard. ${ }^{[39]}$

\subsection{Fluorinated graphite}

Fluorinated graphite is a well-known material in the field of batteries. It has been used as cathode in $\mathrm{Li}^{[40-42]}$ and $\mathrm{Mg}^{[43,44]}$ battery systems where the obtained discharge capacities were relatively high. For Al-ion battery applications, fluorinated graphite was prepared electrochemically using cyclic voltammetry. Here, fluorine ions move in the graphene layers, forming non-covalent $\mathrm{C}-\mathrm{F}$ bond. As a result of that mechanism, the space between the graphene sheets expanded ${ }^{[22]}$ meaning more $\mathrm{Al}$ ions could potentially intercalate between layers of carbon atoms. In Figure 5, the SEM images of non-fluorinated and fluorinated graphite are compared where the changes in morphology suggest sheet expansion as the outcome of fluorine intercalation. The graphite crystal structure after intercalation remained stable revealing a beneficial characteristic of the material.

\section{[Figure 5]}




\section{WILEY-VCH}

According to the literature ${ }^{[22]}$ the resistivity of fluorinated graphite reduced by half when compared to natural graphite. This is contrary with surface area that increased by a factor of three. From the aspect of mass transfer between the electrolyte and the active material, volume enlargement is beneficial but concerning the material stability this is not favourable. For a battery with a fluorinated graphite cathode and $\mathrm{Al}$ anode, a mixture of $\mathrm{AlCl}_{3}$ and 1,3-di-nbutylimidazolium bromide was used as the electrolyte. ${ }^{[22]}$ After 40 cycles the capacity (225 $\mathrm{mAh} \mathrm{g}^{-1}$ ) remained stable with constant current density during charging/discharging at $60 \mathrm{~mA}$ $\mathrm{g}^{-1}$. The average voltage plateau of the battery was approximately $1.3 \mathrm{~V}$ and the columbic efficiency was limited to only $75 \% .{ }^{[22]}$ This is comparing to other batteries described in the review low. The theoretical energy density of this battery system is $144 \mathrm{Wh} \mathrm{kg}^{-1}$ which is according to the literature, ${ }^{[34]}$ better than various other types of batteries (lead-acid, Ni-Cd, Ni$\mathrm{MH})$.

The utilization of this type of a battery is yet limited due to the low columbic efficiency, inadequate cycle life and low voltage range. Nevertheless the capacity is comparing to other carbon cathode systems ${ }^{[8,21]}$ encouraging.

\subsection{Anatase $\mathrm{TiO}_{2}$}

Anatase is one of the mineral forms of titanium dioxide that is extensively used in many energy $^{[30,45]}$ and self-cleaning ${ }^{[46,47]}$ applications. Its tetragonal crystal symmetry with good stability makes anatase an excellent material for electrochemical Li storage that could result in applications related to $\mathrm{Li}$-ion batteries. ${ }^{[48-50]}$

Anatase $\mathrm{TiO}_{2}$ as an electrode material can exist in different shapes that differ in performance, preparation and stability. The most promising include anatase $\mathrm{TiO}_{2}$ nanotube arrays $\left(\mathrm{TiO}_{2}-\mathrm{NTAs}\right),{ }^{[33,51]} \mathrm{TiO}_{2}$ nanoleaves ${ }^{[52]}$ and $\mathrm{TiO}_{2}$ nanofibers. ${ }^{[53,54]}$ The nanostructure and the surface area of these materials are crucial in order to perform well. $\mathrm{TiO}_{2}$ electrodes possess various positive characteristics that have impact on ion transfer. Among them very important one is high surface area ${ }^{[55]}$ that can ensure good mass transfer between electrode and electrolyte 


\section{WILEY-VCH}

and eventually lead to better diffusion. As mentioned in the beginning $\mathrm{Al}^{3+}$ ion has smaller radius than $\mathrm{Li}^{+}$ion. Therefore, anatase $\mathrm{TiO}_{2}$ storage systems could in principle perform better with $\mathrm{Al}^{3+}$ than $\mathrm{Li}^{+}$ion, respectively. As stated $\mathrm{in}^{[33,51,52]} \mathrm{Al}^{3+}$ ion can be inserted/extracted into/from anatase $\mathrm{TiO}_{2}$ without any electrode volume changes which is related to its stable host structure. This process is associated with the presence of chloride ions that come from the electrolyte. ${ }^{[51]}$ For that reason only certain electrolytes can be used in storage systems with anatase $\mathrm{TiO}_{2}$. Figure 6 shows images of $\mathrm{TiO}_{2}-\mathrm{NTAs}$ before and after $\mathrm{Al}^{3+}$ ion insertion.

\section{[Figure 6]}

It can be seen that the structure remains undamaged and completely filled with ions after ion storage. Both of these characteristics are directly related to the nature of the material, wherein diffusion is dominant for ion insertion. Here the diffusion coefficient is higher as well, than for ion extraction. ${ }^{[51]}$ As a result of unique nanosized geometry of the nanotube arrays, good electrode/electrolyte contact with short ion diffusion path through the electrode is viable.

Unlike $\mathrm{TiO}_{2}$-NTAs, $\mathrm{TiO}_{2}$ nanoparticles prepared via SPP (solution plasma processing) method formed in the shape of willow leaf-like nanostructures (Figure 7), therefore called $\mathrm{TiO}_{2}$ nanoleaves. The structure is the outcome of the congregation of nanoparticles that results in a rough surface. ${ }^{[52]}$ As shown in Figure 7 the size distribution is homogeneous, which can together with their small thickness eventually reflects in better performance.

\section{[Figure 7]}

Furthermore, SPP method is known to be economical and efficient method suitable for large scale production that could express in better manufacture of $\mathrm{TiO}_{2}$ nanoleaves material. In the 
course of operation of the battery with anatase $\mathrm{TiO}_{2}$, redox reactions occur within the material (anode). During charging, reduction takes place:

$\mathrm{Ti}^{4+}+1 \mathrm{e}^{-} \rightarrow \mathrm{Ti}^{3+}$

and during discharging, oxidation takes place: ${ }^{[33,51,52]}$

$\mathrm{Ti}^{3+} \rightarrow \mathrm{Ti}^{4+}+1 \mathrm{e}^{-}$

Deep reduction of $\mathrm{Ti}^{4+}$ to $\mathrm{Ti}^{2+}$ that is known as irreversible redox reaction does not occur on a large scale. Reason for such suppression in anatase $\mathrm{TiO}_{2}$ nanoleaves is the existence of $\mathrm{N}$ and H. ${ }^{[52]} \mathrm{Up}$ to now the maximum discharge capacity that has been obtained in a battery with $\mathrm{TiO}_{2}-$ NTAs using an aqueous $\mathrm{AlCl}_{3}$ solution as an electrolyte is restricted to $75 \mathrm{mAh} \mathrm{g}^{-1}$ (higher than for the commercial white anatase $\left.\mathrm{TiO}_{2}\right)^{[52]}$ with a current density at $4 \mathrm{~mA} \mathrm{~cm}{ }^{-2}$. This current density is to some extent higher than in a system with anatase $\mathrm{TiO}_{2}$ for $\mathrm{Li}^{+}$ions. ${ }^{[33,51]}$ Nevertheless, the life cycle (13 cycles) is still inadequate with poor average voltage plateaus (cca. $0.8 \mathrm{~V}$ ). But according to the research group of $\mathrm{Li}$ and $\mathrm{Gao}^{[33]}$ there is still significant room for improvement in the field of discharge capacity and cycle life. Improved battery systems are therefore expected to be obtained in the future.

Comparing to $\mathrm{TiO}_{2}$ nanoleaves (used in a 3 electrode cell configuration), the obtained reversible capacity in $\mathrm{Al}\left(\mathrm{NO}_{3}\right)$ aqueous electrolyte reached $254.6 \mathrm{mAh} \mathrm{g}^{-1}$ and after 300 cycles decreased by $8.4 \%$ at a rate of $50 \mathrm{~mA} \mathrm{~g}^{-1}$.(52]) This rate together with cyclability is comparing to other Al-ion intercalating batteries relatively high for such a high capacity and is related to the stable porous structure of the nanoleaves where solid state diffusion of $\mathrm{Al}^{3+}$ ions in the bulk was very high. ${ }^{[52]}$ High cycle rate can be attributed to very stable anatase $\mathrm{TiO}_{2}$ structure where the structure distortion upon $\mathrm{Al}^{3+}$ insertion did not occur in contrast to $\mathrm{Li}^{+}$insertion. In the latter 


\section{WILEY-VCH}

insertion, formation of zigzag chains of Ti-Ti bounds occurs meaning the tetragonal structure changes to orthorhombic. ${ }^{[33,52,56]}$ Moreover, at very high current density of $2000 \mathrm{~mA} \mathrm{~g}^{-1}$, the capacity is still $\sim 140 \mathrm{mAh} \mathrm{g}^{-1}$ with a coulombic efficiency close to $100 \%$. Importantly, this measurement was conducted over only 5 cycles, which questions its stability. Nonetheless, this performance could be a result of the ordered nanoparticles in the nanoleaves that are mesoporous, making ion transport easier. ${ }^{[52]}$

In conclusion, anatase $\mathrm{TiO}_{2}$ nanoleaves that performed better than $\mathrm{TiO}_{2}-\mathrm{NTAs}$ showed to be a promising anode material for a cheap Al-ion battery system.

\subsection{Vanadium(V) oxide $\left(\mathrm{V}_{2} \mathrm{O}_{5}\right)$}

Vanadium (V) oxide also known as "vanadia" is the most important compound of vanadium being used in many applications. In the field of battery systems $\mathrm{V}_{2} \mathrm{O}_{5}$ is the most known for being cathode material in Li-ion batteries. ${ }^{[1]}$ In recent years research has been undertaken for Al-ion batteries as well, wherein $\mathrm{V}_{2} \mathrm{O}_{5}$ was tested as a possible cathode.

Different methods of preparation that have significant effect on overall battery performance have been implemented for $\mathrm{V}_{2} \mathrm{O}_{5}$ cathode. The most widespread method includes a direct coating of electrodes by paste; this is usually achieved by mixing $\mathrm{V}_{2} \mathrm{O}_{5}$ powders, a conductive additive (carbon, etc.) and a binder (PVDF, PTFE). An alternative approach is the direct growth of nanoparticles on the electrode, where a binder-free electrode is obtained. In this way the use of ancillary material is reduced, making manufacturing process more environmentally friendly, efficient and economical. The redox reactions that occur during the operation of a battery with $\mathrm{Al}$ anode, $\mathrm{V}_{2} \mathrm{O}_{5}$ cathode and $\mathrm{AlCl}_{3}$ methylimidazolium chloride (electrolyte) can be written as: ${ }^{[20]}$

\section{Discharge:}

anode: $\quad \mathrm{Al}-3 \mathrm{e}^{-} \rightarrow \mathrm{Al}^{3+}$

cathode: $\quad \mathrm{Al}^{3+}+\mathrm{V}_{2} \mathrm{O}_{5}+3 \mathrm{e}^{-} \rightarrow \mathrm{AlV}_{2} \mathrm{O}_{5}$ 


\section{WILEY-VCH}

\section{Charge:}

anode: $\quad 4 \mathrm{Al}_{2} \mathrm{Cl}_{7}^{-}+3 \mathrm{e}^{-} \rightarrow \mathrm{Al}+7 \mathrm{AlCl}_{4}^{-}$

cathode: $\quad \mathrm{AlV}_{2} \mathrm{O}_{5}-3 \mathrm{e}^{-} \rightarrow \mathrm{V}_{2} \mathrm{O}_{5}+\mathrm{Al}^{3+}$

The first application of $\mathrm{V}_{2} \mathrm{O}_{5}$ cathode in reversible Al battery was published by Jayaprakash et $a l{ }^{[11]}$ In their work they fabricated the $\mathrm{V}_{2} \mathrm{O}_{5}$ cathode by coating a stainless steel current collector with the pre-made paste. That paste contained PVDF binder together with other material. The manufactured cathode had the orthorhombic crystal structure suitable for the insertion/deinsertion of $\mathrm{Al}^{3+}$ ions. As a result, they obtained a capacity of $305 \mathrm{mAh} \mathrm{g}^{-1}$ that after 20 cycles decreased by approx. $10 \%$ to $273 \mathrm{mAh} \mathrm{g}^{-1}$ at constant current density of $125 \mathrm{~mA} \mathrm{~g}^{-1}$. The coulombic efficiency and the average voltage plateau (cca. $0.9 \mathrm{~V}$ ) were not as high as desirable, therefore together with poor cycle life decreasing potential practical use. ${ }^{[11]}$ From this, it is possible to assume that only small amounts of $\mathrm{Al}^{3+}$ ions participated in the battery operation, since the theoretical capacity of the battery is $442 \mathrm{mAh} \mathrm{g}^{-1}$. However, despite well cited paper by Jayaprakash and co-workers ${ }^{[11]}$ their results are controversial. As stated in, ${ }^{[57]}$ the electrochemical activity of $\mathrm{V}_{2} \mathrm{O}_{5}$ cathode in $\mathrm{Al}$ battery is the outcome of the stainless steel that was used as a current collector in the cathode. The electrochemical performance of $\mathrm{V}_{2} \mathrm{O}_{5}$ is therefore the result of iron and chromium reactions in the stainless steel. Moreover, the presence of $\mathrm{V}_{2} \mathrm{O}_{5}$ in cathodes is even detrimental.

In contrast to a method of coating the slurry on a stainless steel electrode, Wang and coworkers ${ }^{[20]}$ perform a different approach. In order to enhance the performance of $\mathrm{V}_{2} \mathrm{O}_{5}$ cathodes, a binder-free cathode was made by directly depositing the cathode material on a Ni-foam substrate. ${ }^{[20]}$ As a result, side reactions between the electrolyte and the binder are diminished thus leading to capacity improvement. An SEM image of the as-prepared cathode can be seen in Figure 8a. Compared to the $\mathrm{V}_{2} \mathrm{O}_{5}$ nanowire cathode (a method of Jayaprakash et al. ${ }^{[11]_{-}}$ 


\section{WILEY-VCH}

Figure 8b), a binder-free structure is larger and more three-dimensional, that could eventually lead to better intercalation of $\mathrm{Al}^{3+}$ ions resulting in higher current density and better capacity.

\section{[Figure 8]}

An effect of different types of binders on a battery performance was also examined in the same work. ${ }^{[20]}$ It was discovered that $\mathrm{V}_{2} \mathrm{O}_{5}$ nanowire with PVDF binder had the initial discharge capacity of $46 \mathrm{mAh} \mathrm{g}^{-1}$ at $44.2 \mathrm{~mA} \mathrm{~g}^{-1}$ current density wherein the discharge capacity of $\mathrm{V}_{2} \mathrm{O}_{5}$ nanowire with PTFE binder was $86 \mathrm{mAh} \mathrm{g}^{-1}$. Reason for such a difference lies in the insolubility of PTFE binder in the used electrolyte $\left(\mathrm{AlCl}_{3}\right.$ methylimidazolium chloride) ${ }^{[20]}$ Nevertheless, the highest discharge capacity at the same charge/discharge rate was obtained with a binderfree $\mathrm{Ni}-\mathrm{V}_{2} \mathrm{O}_{5}$ i.e. $239 \mathrm{mAh} \mathrm{g}^{-1}$. Such a difference is result of a better contact between the electrolyte and the three-dimensional cathode structure together with the binder absence thus increasing ion diffusion within the structure of the cathode material. It should be noted that all three measurements were performed for only 5 cycles, where the $5^{\text {th }}$ cycle already gave noticeable lower capacities suggesting the battery is very unstable. Moreover, the average voltage plateau was also low for all three systems in the ranges between $0.8 \mathrm{~V}-1.4 \mathrm{~V}$.

Regardless of high discharge capacity, cycle life, stability and average voltage plateaus are far from being encouraging.

\subsection{Vanadium (V) oxide/Carbon composite $\left(\mathrm{V}_{2} \mathrm{O}_{5} / \mathrm{C}\right)$}

A composite material made of vanadium (V) oxide and carbon composite $\left(\mathrm{V}_{2} \mathrm{O}_{5} / \mathrm{C}\right)$ is as stated in the literature ${ }^{[58-61]}$ being researched in the field of supercapacitors, $\mathrm{Mg}$ and Li-ion batteries. For Al batteries only one paper ${ }^{[62]}$ has been published where the material was used as cathode. $\mathrm{AlCl}_{3}$ imidazolium based chlorides are the most typical used electrolytes for $\mathrm{Al}$-ion batteries. Despite this, they are not the only electrolytes used in such batteries meaning certain alternatives exist. Another approach is to replace imidazolium chloride with a mixture of 


\section{WILEY-VCH}

dipropylsulfone and toluene. This electrolyte was used in a system with $\mathrm{V}_{2} \mathrm{O}_{5} / \mathrm{C}$ cathode and Al anode. ${ }^{[62]}$ The amorphous cathode featured in work was prepared only by mixing raw materials under room temperature conditions meaning the procedure is energy efficient. The SEM image of the $\mathrm{V}_{2} \mathrm{O}_{5} / \mathrm{C}$ cathode can be seen in Figure 9. It can be noticed the morphology is wavy and by some means similar to Figure $8 \mathrm{a}$ which was expected. The cathode had an amorphous structure that is well known in the field of Li-ion batteries ${ }^{[63]}$ since it can lead to high intercalation capacity.

\section{[Figure 9]}

As already described in the section above, a stainless steel current collector might be electrochemically active leading to incorrect results. For that reason Inoue et al. ${ }^{[62]}$ replaced the stainless steel current collector with the one made out of molybdenum. The discharge capacity of their battery cell had a value of approximately $150 \mathrm{mAh} \mathrm{g}^{-1}$ at $\mathrm{C} / 20$ charge/discharge rate after the initial cycle. After 30 cycles at the same rate, the capacity dropped down to approx. 65 $\mathrm{mAh} \mathrm{g}^{-1}$ with steady coulombic efficiency and average voltage plateau cca. $1.2 \mathrm{~V} .^{[62]}$ This is more than a $50 \%$ decrease meaning the electrode stability is poor. A reason for such instability could be vanadium reduction that takes place simultaneously with $\mathrm{Al}^{3+}$ intercalation. As observed at almost all other Al batteries, the discharge capacity of this cell increased at lower charge/discharge rates and decreased at higher rates which is related to mass transfer between the ions and the electrode, respectively. The best electrode stability was achieved at $\mathrm{C} / 10$ rate with very low discharge capacity of approx. $55 \mathrm{mAh} \mathrm{g}^{-1}$ at the initial cycle and approx. $50 \mathrm{mAh}$ $\mathrm{g}^{-1}$ at the $30^{\text {th }}$ cycle. ${ }^{[62]}$

Thus the theoretical discharge capacity of the pre described battery during the first discharging was almost reached where making improvements to this are somewhat limited. 


\section{WILEY-VCH}

Batteries using $\mathrm{V}_{2} \mathrm{O}_{5} / \mathrm{C}$ as the cathode material are comparable to other cells described in this review together with its insufficient cyclability being not so promising.

\subsection{VO2 (Vanadium (IV) oxide)}

Vanadium (IV) oxide is another material being described in this review that might be used as a possible electrode in Li-ion batteries. ${ }^{[64]}$ Until now, not a lot of research has been done for $\mathrm{Al}$ batteries therefore published literature is scarce.

Owing to its monoclinic crystal structure, the intercalation mechanism is similar to so called "rocking chair" Li-ion battery system ${ }^{[65]}$ (ions move from cathode to anode and vice versa). The structure of $\mathrm{VO}_{2}$ consists of four channels where $\mathrm{Al}^{3+}$ ions can intercalate. When ions intercalate in one of the channels, others are influenced as well. Al atoms in a channel occupy the intervals of the V-O tunnels. When two $\mathrm{Al}$ ions are in the structure, the charges are negligible. Upon increasing their number above 2 the cell volume is enlarged, resulting in the breaking of the V-O chemical bonds. ${ }^{[23]}$ The latter is not favourable and can affect the battery stability. A detailed description of the intercalation system wherein $\mathrm{Al}$ is used as anode, $\mathrm{AlCl}_{3}$ methylimidazolium chloride as electrolyte and $\mathrm{VO}_{2}$ as the cathode is presented in Figure $\mathbf{1 0}$.

\section{[Figure 10]}

Here, $\mathrm{Al}^{3+}$ ions constantly intercalate/deintercalate into/from $\mathrm{VO}_{2}$ thereby indicating the importance of stable and permeable cathode structure that has the main influence on overall battery performance.

The redox reactions that take place in such a battery cell can be written as: ${ }^{[23]}$

\section{Discharge:}

anode: $\quad \mathrm{Al} \rightarrow \mathrm{Al}^{3+}+3 \mathrm{e}^{-}$

cathode: $\quad \mathrm{VO}_{2}+\mathrm{Al}^{3+}+3 \mathrm{e}^{-} \rightarrow \mathrm{AlVO}_{2}$ 


\section{Charging:}

anode: $\quad \mathrm{Al}^{3+}+3 \mathrm{e}^{-} \rightarrow \mathrm{Al}$

cathode: $\quad \mathrm{AlVO}_{2}-3 \mathrm{e}^{-} \rightarrow \mathrm{VO}_{2}+\mathrm{Al}^{3+}$

The surface area of $\mathrm{VO}_{2}$ cathode (Figure 11) is in the form of flower-like clusters. Comparing to other cathode materials described in this review, this surface morphology is not ideal for an intercalation mechanism as it does not include any large channels (perforated structure ${ }^{[8,26]}$ ), neither is in the form of layers. ${ }^{[22]}$

\section{[Figure 11]}

According to Wang et al. ${ }^{[23]}$ after 100 cycles the highest discharge capacity (116 $\left.\mathrm{mAh} \mathrm{g}^{-1}\right)$ obtained was at $50 \mathrm{~mA} \mathrm{~g}^{-1}$ current density. Such a combination of cycles and capacity is one of the first ever published for Al-ion batteries. At higher charge/discharge rates the discharge capacities reduced, i.e. at $100 \mathrm{~mA} \mathrm{~g}^{-1}$ to $106 \mathrm{mAh} \mathrm{g}^{-1}$ and at $200 \mathrm{~mA} \mathrm{~g}{ }^{-1}$ to $70 \mathrm{mAh} \mathrm{g}^{-1}$, respectively.

Together with low average voltage plateaus, the pre described battery still requires further modifications.

\subsection{Copper hexacyanoferrate}

Prussian blue is a material known for having several analogues. One of them that can be used for Al-ion batteries is copper hexacyanoferrate $(\mathrm{CuHCF})$. Until now, a lot of research work has been done exploring applications of prussian blue analogues (PBAs) for hydrogen storage, ${ }^{[66]}$ organometallic magnets, ${ }^{[67]}$ biosensors, ${ }^{[68]}$ battery electrodes, ${ }^{[9,35]}$ etc.

The molecular formula of copper hexacyanoferrate can be derived from the general formula of PBAs that is written as $\mathrm{A}_{\mathrm{x}} \mathrm{M}_{\mathrm{k}}\left[\mathrm{N}(\mathrm{CN})_{6}\right]_{1} \cdot \mathrm{nH}_{2} \mathrm{O}$. Here $\mathrm{A}$ is an alkali metal-ion and $\mathrm{M}$ 


\section{WILEY-VCH}

and $\mathrm{N}$ are transition metal ions. ${ }^{[69]}$ As claimed by the Gao group ${ }^{[70]} \mathrm{CuHCF}$ prepared by a coprecipitation method had the formula of $\mathrm{KCu}\left[\mathrm{Fe}(\mathrm{CN})_{6}\right] \cdot 8 \mathrm{H}_{2} \mathrm{O}$. In this formula, eight water molecules present zeolitic water content which has a positive effect with ion intercalation. It is known for $\mathrm{Al}$ ions to have three valence electrons meaning its charge is high. As a consequence, interactions between the host material and the ion could prevent ion ability to move leading to disabled battery charging. In order to restrain this, zeolitic water can act as a charge shield thus reducing interactions and allowing free ion transport. Figure 12 shows an SEM image of CuHCF. The morphology of the material displays the structure that is not perforated revealing disadvantage of the material. On the other hand aggregated nanoparticles can perform greatly in a way of enhancing mass transfer between the electrolyte and the active material.

\section{[Figure 12]}

CuHCF framework is shown in Figure 13. As seen the cubic structure has open framework with interstitial sites and open channels allowing ion intercalation. The ion intercalation in the framework at the tetrahedrally coordinated A sites is only partial resulting in lower capacities obtained. ${ }^{[71]}$ The reason for this is because strong bonding between $\mathrm{Al}^{3+}$ ions and $\mathrm{CN}$ ligands occurs. ${ }^{[0]}$ When organic electrolyte (Al triflate dissolved in diglyme) was used, $\left(\mathrm{Al}(\mathrm{DI}) 2^{3+}\right.$ ) namely diglyme-chelated $\mathrm{Al}$-ions were intercalated in the $\mathrm{CuHCF}^{[71]}$ as opposed to $\mathrm{Al}^{3+}$ or hydrated $\mathrm{Al}^{3+}$ intercalating ions when the electrolyte was aqueous $\left(\mathrm{Al}_{2}\left(\mathrm{SO}_{4}\right)_{3}\right.$ solution $) .{ }^{[70]}$

\section{[Figure 13]}

Related to a possible battery application charge/discharge tests were conducted for a $\mathrm{CuHCF}$ material. ${ }^{[70,71]}$ It is worth indicating those tests were performed on a three-electrode cell configuration. When having aqueous electrolyte ${ }^{[70]}$ the highest discharge capacity attained was 


\section{WILEY-VCH}

cca. $63 \mathrm{mAh} \mathrm{g}^{-1}$ at $50 \mathrm{~mA} \mathrm{~g}^{-1}$ with discharge voltage plateau $0.8 \mathrm{~V}$. With increased current density (400 $\mathrm{mA} \mathrm{g}^{-1}$ ) the capacity decreased to $47 \mathrm{mAh} \mathrm{g}^{-1}$. Considering 8 fold increase the capacity retention was very high revealing a beneficial characteristic of CuHCF. After 1000 cycles at $400 \mathrm{~mA} \mathrm{~g}^{-1}$ charge/discharge rate the discharge capacity diminished to approx. 23 $\mathrm{mAh} \mathrm{g}^{-1}$ with constant coulombic efficiency near $100 \%$. In contrast to aqueous electrolyte measurements performed in organic electrolyte ${ }^{[71]}$ gave even lower discharge capacities with worse cyclability.

Despite the easily scaled up method of CuHCF preparation and its low cost, the discharge capacities are inherently low. Therefore as such, incompatible for a battery application. We believe CuHCF is more suitable for applications involving supercapacitors rather than batteries.

\subsection{Mo6Ss (Chevrel phase molybdenum sulfide)}

$\mathrm{Mo}_{6} \mathrm{~S}_{8}$ is well known as a cathode material in the field of rechargeable $\mathrm{Mg}$ batteries. ${ }^{\left[{ }^{[2]}\right.} \mathrm{Up}$ to now research has only focused on cation intercalation with one or two positive charges $\left(\mathrm{Li}^{+}\right.$, $\mathrm{Na}^{+}, \mathrm{Mg}^{2+}$, etc.) within its crystal structure. ${ }^{[6,73,74]}$ Recently a paper ${ }^{[24]}$ was published wherein reversible electrochemical $\mathrm{Al}$ intercalation (three positive charges) was reported.

It can be seen from this review that many cathode materials for Al batteries include transition metal oxides. These oxides have strong electrostatic attraction with Al ions. As a result of that their structure can negatively affect $\mathrm{Al}$ ion intercalation, thus reduce the battery performance. In order to diminish this effect structures without oxygen (high electronegativity) can serve as an alternative. Guo and co-workers ${ }^{[24]}$ proposed one alternative by synthesizing a $\mathrm{Mo}_{6} \mathrm{~S}_{8}$ cathode material (Figure 14).

\section{[Figure 14]}




\section{WILEY-VCH}

Figure 14 shows that she shape of the particles is cubic and approximately $1 \mu \mathrm{m}$ in size. It can also be seen that the structure is not perforated which is not ideal for intercalation mechanism. The crystal structure of $\mathrm{Mo}_{6} \mathrm{~S}_{8}$ can be seen in Figure 15. The structure consists of stacked $\mathrm{Mo}_{6} \mathrm{~S}_{8}$ blocks that constitute of a sulfur cubic cell where the octahedral cluster of Mo atoms are present. Between $\mathrm{Mo}_{6} \mathrm{~S}_{8}$ units, $\mathrm{Al}$ atoms are intercalated in two different sites that are distinct in terms of size. Site $\mathrm{Al}_{1}$ is situated as a cubic center of a hexahedron with light blocks of $\mathrm{Mo}_{6} \mathrm{~S}_{8}$ representing the vertices whereas the smaller site, $\mathrm{Al}_{2}$ is situated as face centered. In regards to intercalation, $\mathrm{Al}$ ions can be inserted into the larger $\mathrm{Al}_{1}$ site easier than into the $\mathrm{Al}_{2}$ site. ${ }^{[24]}$ Importantly, the degree of volume change after $\mathrm{Al}^{3+}$ intercalation is smaller when compared to $\mathrm{Li}^{+}$or $\mathrm{Mg}^{2+}$ ion insertion, which is beneficial in regards to material stability. ${ }^{[75]}$

[Figure 15]

The proposed redox reactions for the battery system with $\mathrm{Mo}_{6} \mathrm{~S}_{8}$ cathode and $\mathrm{AlCl}_{3}$ imidazolium chloride are: ${ }^{[24]}$

Discharge:

anode $: \quad \mathrm{Al}+7\left[\mathrm{AlCl}_{4}\right]^{-} \rightarrow 4\left[\mathrm{Al}_{2} \mathrm{Cl}_{7}\right]^{-}+3 \mathrm{e}^{-}$

cathode: $\quad 8\left[\mathrm{Al}_{2} \mathrm{Cl}_{7}\right]^{-}+6 \mathrm{e}^{-}+\mathrm{Mo}_{6} \mathrm{~S}_{8} \rightarrow \mathrm{Al}_{2} \mathrm{Mo}_{6} \mathrm{~S}_{8}+14\left[\mathrm{AlCl}_{4}\right]^{-}$

\section{Charge:}

anode: $\quad 4\left[\mathrm{Al}_{2} \mathrm{Cl}_{7}\right]^{-}+3 \mathrm{e}^{-} \rightarrow \mathrm{Al}+7\left[\mathrm{AlCl}_{4}\right]^{-}$

cathode: $\quad \mathrm{Al}_{2} \mathrm{Mo}_{6} \mathrm{~S}_{8}+14\left[\mathrm{AlCl}_{4}\right]^{-} \rightarrow 8\left[\mathrm{Al}_{2} \mathrm{Cl}_{7}\right]^{-}+6 \mathrm{e}^{-}+\mathrm{Mo}_{6} \mathrm{~S}_{8}$

As stated in ${ }^{[24]}$ the highest discharge capacity obtained in the pre described battery configuration took place after the first discharge $\left(148 \mathrm{mAh} \mathrm{g}^{-1}\right)$ at $12 \mathrm{~mA} \mathrm{~g}^{-1}$. A drawback here presents the current density that is very low. Interestingly, the coulombic efficiency boosted is over $100 \%$. 


\section{WILEY-VCH}

The only explanation for this performance could be attributed to trapped $\mathrm{Al}$ atoms in the cathode structure. ${ }^{[24]}$ Furthermore, by analysing the XRD patterns, Lee et al. ${ }^{[75]}$ proposed the final discharge product to be $\mathrm{Al}_{4 / 3} \mathrm{Mo}_{6} \mathrm{~S}_{8}$ instead of $\mathrm{Al}_{2} \mathrm{Mo}_{6} \mathrm{~S}_{8}$ as stated by Geng et al. ${ }^{[24]}$ In the same same work, the discharge curve of the first cycle was discussed as well, explaining that the initial part of the curve is related to the electrolyte decomposition and not the intercalation mechanism. ${ }^{[75]}$ However, after the first few cycles the discharge capacity remained to a moderate extent stable at the value of $70 \mathrm{mAh} \mathrm{g}^{-1}$ at the end of the $50^{\text {th }}$ cycle. During these 50 cycles the coulombic efficiency was still slightly above $100 \%$ meaning Al trapping was present. When the current density of the battery was manipulated, decreased discharge capacities appeared at higher rates and increased at lower rates. For instance at $6 \mathrm{~mA} \mathrm{~g}^{-1}$ the discharge capacity increased up to $80 \mathrm{mAh} \mathrm{g}^{-1}$ and at $125 \mathrm{~mA} \mathrm{~g}^{-1}$ down to $25 \mathrm{mAh} \mathrm{g}^{-1}$. ${ }^{(24])}$ It is worth mentioning that these measurements were performed at $50{ }^{\circ} \mathrm{C}$. At room temperature values are somewhat different. The discharge capacity at the same current density is limited to only approx. $30 \mathrm{mAh} \mathrm{g}^{-1}$ after even less cycles (25) with unstable coulombic efficiency. This behaviour could be the outcome of different $\mathrm{Mo}_{6} \mathrm{~S}_{8}$ particles size as electrolyte at elevated temperatures is not significantly affected. ${ }^{[24]}$

Therefore, certain improvements still need to be done. In terms of practical applications the battery system is appealing as theoretical energy density is $90 \mathrm{~W} \mathrm{~h} \mathrm{~kg}^{-1}$ (multiplying with $0.5 \mathrm{~V}$ ) if the discharge product is considered to be $\mathrm{Al}_{2} \mathrm{Mo}_{6} \mathrm{~S}_{8}$ which is close to Ni-MH battery technology. ${ }^{[34]}$ Nonetheless, if $\mathrm{Al}_{4 / 3} \mathrm{Mo}_{6} \mathrm{~S}_{8}$ is taken into account the theoretical capacity is lower.

\subsection{Conductive polymers}

The discovery of organic polymers that conduct electricity was awarded the Nobel Prize in chemistry for the year 2000. Conductive polymers can be used in a range of applications such as solar cells, ${ }^{[76]}$ chemical sensors, ${ }^{[77]}$ diodes,${ }^{[78]}$ electrochemical capacitors, ${ }^{[79]}$ etc. Moreover, conductive polymers have also been widely explored in the field of $\mathrm{Li}$-ion batteries. ${ }^{[37]}$ 


\section{WILEY-VCH}

In order to use a conductive polymer for an electrode material in a three electrode Al battery cell configuration it first has to be polymerized. Polymers, namely pyrrole and thiophene that can be used in such a configuration are polymerized electrochemically i.e. via electropolymerization. A solution used for this process consists of the corresponding monomer and $\mathrm{AlCl}_{3}$ imidazolium chloride (electrolyte). ${ }^{[25]}$ As a result of electropolymerization a conducting polymer is doped with anions from the electrolyte. In the case of polypyrrole and polythiophene chloroaluminate-doped $\left(\mathrm{AlCl}_{4}^{-}\right.$and $\left.\mathrm{Al}_{2} \mathrm{Cl}_{7}^{-}\right)$polymers were obtained. ${ }^{[25]}$ In contrast to a three-electrode cell configuration, electrode fabrication for Swagelok-type cells ( $\mathrm{Al}$ anode, electrolyte and cathode) are different. According to the work of Hudak ${ }^{[25]}$ composite $^{2}$ cathode was made of a conducting polymer (polypyrrole or polythiophene), an organic polymer binder and a conductive additive. In terms of redox reactions, they are almost identical to what has already been described in this review for the other systems. That is, from the left to the right for discharge and the opposite for cell charge:

$$
\mathrm{Al}+4 \mathrm{AlCl}_{4}^{-}+3\left(\mathrm{X}^{+} \mathrm{AlCl}_{4}^{-}\right) \leftrightarrow 4 \mathrm{Al}_{2} \mathrm{Cl}_{7}^{-}+3 \mathrm{X}
$$

Where $\mathrm{X}$ represents a cathode host (a conductive polymer) for intercalating ions.

Cycling behaviour for the two conducting polymers is described in the pre mentioned work of Hudak. ${ }^{[25]}$ Hudak's work describes configurations performed in a Swagelok-type cell and in a three-electrode cell configuration. It was discovered that polythiophene is a better cathode material for Al-ion battery than polypyrrole. The reason for that is higher discharge capacity of polythiophene cathode (approx. $85 \mathrm{mAh} \mathrm{g}^{-1}$ ) where polypyrrole cathode gave approx. $70 \mathrm{mAh}$ $\mathrm{g}^{-1}$ after the first cycle. Both cathodes have the same voltage limits of $0.8 \mathrm{~V}$ (lower limit) and 2.0 V (upper limit). Furthermore, polypyrrole powder in the composite cathode was in a doped or partially doped state (undoped state is unstable in air) contrary to polythiophene powder which was in undoped form. ${ }^{[25]}$ Upon manipulating with voltage limits (lower upper limit) the 


\section{WILEY-VCH}

discharge capacities for both polymers decreased. The cycling stability of both polymers was evaluated at the current density of $20 \mathrm{~mA} \mathrm{~g}^{-1}$ for polypyrrole and $16 \mathrm{~mA} \mathrm{~g}^{-1}$ for polythiophene. ${ }^{[25]}$ After 100 cycles at voltage limits written above the capacity of polythiophene decreased for about $17.7 \%$ (approx. $70 \mathrm{mAh} \mathrm{g}^{-1}$ ) and for polypyrrole cca. $31.4 \%$ (approx. 48 $\left.\mathrm{mAh} \mathrm{g}^{-1}\right)$. Coulombic efficiencies for both polymers were over $91 \%$ during all cycles. The reason for capacity reduction may be due to the binder used for the composite cathode that had affect on active material loss. ${ }^{[25]}$ The organic polymer binder is usually used for Li-ion batteries meaning different type should be applied for Al-ion batteries. Therefore improvements can still be made in order to decrease the capacity decay besides increasing the discharge capacity for polypyrrole as theoretical capacity has not been reached. Comparing these capacity values (Swagelok type cells) with the capacities from the three-electrode cell configuration it can be noted that at the same voltage limits polythiophene gave once again higher capacity than polypyrrole. ${ }^{[25]}$ Additionally, this proves that polythiophene is a better cathode material for Alion battery.

Comparing to other battery systems described in this review, conductive polymers do not offer any significant breakthrough in any of the battery-relevant metrics.

\subsection{Sulfur}

The idea of using sulfur in a battery cell configuration could be as a result of its abundance very attractive. Moreover, certain metal-sulfur battery systems including $\mathrm{Li} / \mathrm{S}$ and $\mathrm{Na} / \mathrm{S}$ have already been extensively studied due to their attractive theoretical energy capacity values. ${ }^{[80-83]}$ Together with them others e.g. K/S or Al/S have been proposed as well. ${ }^{[84-86]}$ In most of these systems organic solvents were used as opposed to $\mathrm{AlCl}_{3}$ imidazolium chloride based ionic liquids that are common in batteries described in chapters above.

According to the literature, a battery based on $\mathrm{Al}$ anode, sulfur cathode and $\mathrm{AlCl}_{3}$ imidazolium chloride was first published by the group of Archer et al. ${ }^{[26]}$ where they claimed the battery operates via electrochemical conversion of chloroaluminate instead of intercalation. 


\section{WILEY-VCH}

The process is mostly a result of diffusion therefore concentration difference is the major force for chloroaluminate conversion. Herein the main ion is $\mathrm{AlCl}_{4}^{-}$. It is noteworthy that the process does not occur if only $\mathrm{AlCl}_{4}^{-}$ion is in the electrolyte meaning it has to be acidic hence other anions $\left(\mathrm{Al}_{2} \mathrm{Cl}_{7}^{-}\right)$are formed. Figure 16 shows an SEM image of the sulfur cathode that was made by coating the slurry on stainless steel. ${ }^{[26]}$ It can be seen that the particles are homogeneously covered on the surface with tiny holes between them.

\section{[Figure 16]}

One of the biggest advantages of this battery is very high theoretical capacity (approx. 1670 $\mathrm{mAh} \mathrm{g}^{-1}$ ) that was remarkably almost reached (approx. $1600 \mathrm{mAh} \mathrm{g}^{-1}$ ) at the current density of $20 \mathrm{~mA} \mathrm{~g}^{-1} \cdot{ }^{([26])}$ This is by far the highest discharge capacity ever achieved in Al-ion batteries. As noticed at other cathode materials the discharge capacity decreases with higher current density. Sulfur cathode is not an exception as at $120 \mathrm{~mA} \mathrm{~g}^{-1}$ the capacity decreased to 1200 $\mathrm{mAh} \mathrm{g}^{-1}$ which is still extraordinary high. In contrast to the discharge capacity, the average voltage plateaus is not as high (1.2 V the highest) as values in other Al batteries discussed in the review. Additionally, there is a limitation due to the number of cycles which can be achieved. After the first cycle the capacity dropped to approx. $200 \mathrm{mAh} \mathrm{g}^{-1}$ and after the fourth cycle it was negligible. This phenomenon is the result of irreversible dissolution of discharge species that include sulfur which completely dissolved in the electrolyte. ${ }^{[26]}$ Therefore the cathode material was unable to recharge due to the absence of sulfur. Similar behavior was already published for $\mathrm{Li} / \mathrm{S}$ and $\mathrm{Na} / \mathrm{S}$ batteries. ${ }^{[83,87]}$

Despite some undeniable restrictions of the sulfur cathode there are certain advantages of Al/S batteries. One of them is natural abundance and low price of both elements. Together with high discharge capacity and low safety risk of $\mathrm{Al} / \mathrm{S}$ batteries, suggests that they could potentially serve as a single use battery for various applications. Furthermore, one possibility 


\section{WILEY-VCH}

is to change only the cathode while leaving the anode and the electrolyte intact. Archer et al. ${ }^{[26]}$ proposed a prototype for a technique of cathode replacement. They also showed that the capacity loss is minimal upon replacing the cathode. We assume that the $\mathrm{Al} / \mathrm{S}$ battery configuration has prospects of commercialization if a new electrolyte for Al batteries that does not dissolve sulfur would be discovered.

\subsection{4. $\mathrm{FeS}_{2}$ (Pyrite)}

Pyrite is one of the most common types of minerals comprised of sulphide ion. Typically it is used for the production of sulfur dioxide, in the manufacture of sulphuric acid, as a gemstone, etc. The mineral is an abundant and inexpensive material being researched as a cathode material for Li-ion and Na-ion batteries. ${ }^{[88-90]}$ In the 80 's attempts to utilize it for Al batteries were made but without any commercial value. ${ }^{[91]}$

As the material has a very high theoretical capacity i.e. $894 \mathrm{mAh} \mathrm{g}^{-1}$ applications related to energy storage can be very appealing. In that matter Uchimoto et al. ${ }^{[92]}$ employed a twoelectrode cell configuration where they used $\mathrm{Al}$ as the anode, a mixture comprised of $\mathrm{FeS}_{2}$, vapour-grown carbon fiber and PTFE binder on Mo foil as the cathode and $\mathrm{AlCl}_{3}$ imidazolium chloride as the electrolyte. Here the $\mathrm{FeS}_{2}$ particle size in the cathode was related to the battery performance meaning higher capacity value was obtained with smaller particle size (illustrated in Figure 17) as a result of better mass transfer between the material and the electrolyte.

\section{[Figure 17]}

Figure 18 shows the pyrite structure of $\mathrm{FeS}_{2}$. The structure is simple cubic where the unit cell is composed of a Fe face centred cubic sublattice with integrated $\mathrm{S}$ ions. The reaction between $\mathrm{Al}$ and disulphide ions occurs through the following reduction:

$\mathrm{S}_{2}^{2-} \leftrightarrows 2 \mathrm{~S}^{2-}$ 


\section{WILEY-VCH}

The $\mathrm{FeS}_{2}$ phase transforms to the $\mathrm{FeS}$ and $\mathrm{Al}_{2} \mathrm{~S}_{3}$ phase as illustrated in Figure 18. Since the reaction is reversible, $\mathrm{FeS}$ and $\mathrm{Al}_{2} \mathrm{~S}_{3}$ phases revert back to $\mathrm{FeS}_{2}$ after charging. ${ }^{\text {[92] }}$

[Figure18]

As stated in ${ }^{[92]}$ the battery operates according to the following reaction during discharge:

$\mathrm{FeS}_{2}+\frac{2}{3} \mathrm{Al}^{3+}+2 \mathrm{e}^{-} \rightarrow \mathrm{FeS}+\frac{1}{3} \mathrm{Al}_{2} \mathrm{~S}_{3}$

After FeS and $\mathrm{Al}_{2} \mathrm{~S}_{3}$ are generated, they can be converted back to $\mathrm{FeS}$ z after the charging process. The discharge capacity obtained was comparing to other Al cells discussed herein exceptionally high i.e. around $600 \mathrm{mAh} \mathrm{g}^{-1}$ at $\mathrm{C} / 50$ rate. However, as sulphides are easy to dissolve in $\mathrm{AlCl}_{3}$ imidazolium chloride the battery is unstable. The same phenomenon was already observed with the sulfur cathode ${ }^{[26]}$ meaning materials containing sulfur are despite their promising discharge capacities unsuitable for battery cells implementing used electrolytes.

Together with poor cycle stability and low cell voltage (cca. $1.2 \mathrm{~V}$ ), other battery parameters apart of the capacity are not high as well. It is noteworthy that the mechanism operates at $55^{\circ} \mathrm{C}$, higher than most of the $\mathrm{Al}$ batteries and inappropriate for commercial use.

\subsection{5. $\mathrm{LiFePO}_{4}$ (Lithium iron phosphate)}

In contrast to previous battery systems described herein, a combination of Li and Al chemistry implemented together in a cell is feasible as well. Comparing to Li batteries, a combination is advantageous as earth abundant $\mathrm{Al}$ is used together with a safer ionic liquid electrolyte namely $\mathrm{AlCl}_{3}$ imidazolium chloride. As a cathode material, $\mathrm{LiFePO}_{4}$ that is well recognized in the field of commercial Li-ion batteries ${ }^{[93]}$ is employed. 


\section{WILEY-VCH}

This hybrid battery operates through intercalation mechanism but as opposed to usuat other $\mathrm{Al}$ batteries the intercalation ion is $\mathrm{Li}^{+}$cation. The reactions that occur during the cell operation are as follows ${ }^{[94]}$ (from the left to the right for discharge and the opposite for charge):

anode: $\quad \mathrm{Al}+7 \mathrm{LiAlCl}_{4}-3 \mathrm{e}^{-} \leftrightarrow 4 \mathrm{LiAl}_{2} \mathrm{Cl}_{7}+3 \mathrm{Li}^{+}$

cathode: $\quad 3 \mathrm{FePO}_{4}+3 \mathrm{Li}^{+}+3 \mathrm{e}^{-} \leftrightarrow 3 \mathrm{LiFePO}_{4}$

It is noteworthy that as stated in, ${ }^{[94]} \mathrm{LiAlCl}_{4}$ was added to the electrolyte. This is due to its improved kinetics of the cell reactions that results in higher battery relevant parameters. The cathode was fabricated by applying a mixture of $\mathrm{LiFePO}_{4}$, Super $\mathrm{P}$ carbon and PTFE binder on an E-Tek carbon cloth current collector. ${ }^{[94]}$ The initial discharge capacity of the pre described battery configuration was as high as $160 \mathrm{mAh} \mathrm{g}^{-1}$ with average voltage plateau $1.0 \mathrm{~V}$ that gradually decreased after the first few cycles to $122 \mathrm{mAh} \mathrm{g}^{-1}$ where it remained stable after 50 cycle numbers at $\mathrm{C} / 5$ current density. During the operation, the columbic efficiency was very high and constantly close to $100 \%$. Upon manipulating with charge/discharge rates, the discharge capacity changed i.e. at 5 times higher rate (1C) it decreased to $71 \mathrm{mAh} \mathrm{g}^{-1}$ and stayed stable after approximately 25 cycles. With higher current density of $2 \mathrm{C}$ the capacity dropped down to around $44 \mathrm{mAh} \mathrm{g}^{-1}$. Different current densities did not have any significant effect on the coulombic efficiency meaning it was always near $100 \% .{ }^{[94]}$ All these values were without the addition of $\mathrm{LiAlCl}_{4}$ to the electrolyte lower, respectively.

The highest strength of $\mathrm{LiFePO}_{4}$ cathode is its discharge capacity. However, comparing to other cathode materials and considering other figures of merit, better alternatives exist in the state of art discussed in this review. Al batteries. In addition, the use of Li metal is not omitted in this battery system meaning that alternatives comprised of only earth abundant and cheap materials would be also more cost effective. 


\section{WILEY-VCH}

\section{Conclusion}

This review has summarized the recent trends in Al-ion batteries as a promising, affordable, and more abundant alternative to Li-based systems. Among other alternatives to $\mathrm{Li}$ such as, $\mathrm{Mg}$, $\mathrm{Na}, \mathrm{Ca}$ and $\mathrm{K}, \mathrm{Al}$ is still the most abundant material where its use in high performing batteries could offer significant advances in terms of price and sustainability. Research into Al-ion batteries has become more extensive in the last 5 years. Before, their application was hindered by difficulties caused by aqueous electrolytes. ${ }^{[12]}$ Despite a paper from Glifford and Palmisano in year 1988 where a non-aqueous electrolyte i.e. $\mathrm{AlCl}_{3}$ imidazolium chloride was used in an electrochemical cell ${ }^{[55]}$, not a lot of research implementing the same electrolyte for Al-ion batteries has been undertaken afterwards.

i. In the majority of the battery systems discussed in this review, the electrolyte was an $\mathrm{AlCl}_{3}$ imidazolium chloride based ionic liquid that differed in these batteries depending on the molar ratio between $\mathrm{AlCl}_{3}$ and ionic liquid. This electrolyte was very problematic in the battery cell with a sulfur cathode where the highest and very appealing discharge capacity of $1600 \mathrm{mAh} \mathrm{g}^{-1}$ was reached. ${ }^{[26]}$ Unfortunately, the sulfide products completely dissolved in the electrolyte used, leading to limited electrode stability, respectively.

ii. In the battery configurations with a $\mathrm{TiO}_{2}$ cathode, aqueous electrolytes were used. These electrolytes are safer, less flammable and more environmentally friendly compared to organic ionic liquids, which can be beneficial in terms of potential commercial use. 


\section{WILEY-VCH}

iii. Another significant factor for the overall battery performance is the cathode morphology. According to this review, the highest values of battery relevant metrics were obtained with structures that were perforated, consequently good ion $\left(\mathrm{Al}^{3+}\right)$ or polyatomic ion $\left(\mathrm{AlCl}_{4}^{-}, \mathrm{Al}_{2} \mathrm{Cl}_{7}^{-}\right)$intercalation/deintercalation was enabled. An excellent example of this structure is the graphitic foam where impressive stability (7500 cycles) and current density (4000 mA g ${ }^{-1}$ ) were reached, respectively. Many cathode materials were also in the form of nanoparticles. These nanoparticles have to be small so the mass transfer between electrolyte and active material is enhanced as a result of high surface area. An important characteristic of a material that has to be considered during intercalation mechanism is the material expansion. The electrode volume has to remain constant during charging/discharging since this is related to the number of cycles achieved in a battery configuration.

iv. The fabrication technique of many cathodes consisted of coating slurry on stainless steel that acts as a current collector. It is noteworthy, that this method could lead to false results, as reported by Reed and Menke. ${ }^{59}$ For that reason, stainless steel should be coated or replaced by alternatives, for instance Mo current collector. An important aspect that has to be considered for an Al-ion battery to be appealing for commercialization is the cathode fabrication process. This process has to be costeffective, preferably consisting of cheap and earth abundant elements. In that regards, carbon-based, titanium and sulfur configurations are in advantage compared to other materials.

v. In comparison to Li batteries, Al-based configurations have high values in all battery relevant metrics are yet to be reported. Among them, the most promising system with high stability and coulombic efficiency together with outstanding charge/discharge rate 


\section{WILEY-VCH}

was with graphitic foam cathode. Nevertheless, the average voltage plateaus and the discharge capacity were inherently low demonstrating major drawbacks of the battery. Contradictory, the battery with sulfur cathode had high discharge capacity but low other figures of merit, respectively.

In order to reduce greenhouse gas emissions and with the electric vehicle market on the rise, research towards high performing batteries is imperative. While Li-ion batteries are still leading the way in terms of performance, their low natural resources are a limitation to future trends. Recent trends in Al-ion batteries have been discussed in this review and their advantages and disadvantages have been highlighted above. Given the significant improvements in Al-ion batteries in recent years, high performing batteries based on these systems are expected to rise in the near future.

\section{Future directions}

i. Although the theoretical performance indicator of $\mathrm{Al}$ anode (Table 1) is much higher in terms of volumetric energy density and almost as high in terms of gravimetric energy density when compared to $\mathrm{Li}$; LIB are currently still better in regards to practical energy densities obtained. In order to achieve such high theoretical values in Al-ion battery configurations, electrolyte and cathode materials have to possess the following characteristics: Firstly, the electrolyte has to allow good ionic conductivity for $\mathrm{Al}^{3+}$ ions which can lead to improved electrochemical intercalation and deintercalation of ions at both electrodes, its electrochemical stability window has to be wide in the presence of $\mathrm{Al}$ anode $^{[11]}$ and all moles of ions from the electrolyte have to participate in redox reactions. In addition, the cathode has to be stable and perforated so the electrolyte can wet and permeate the pores of the structure. While $\mathrm{Al}$ is in theory a very good candidate for high performing batteries, energy densities comparable to LIB have not been 


\section{WILEY-VCH}

obtained yet. It should be noted that the values of energy density differ in every battery configuration discussed in this review, because this is depends on the cathode material used. In order to reach theoretical values, research into novel cathode materials has to be performed together with improvements of the electrolyte. If a good combination of a cathode materials and suitable electrolyte was together paired with an $\mathrm{Al}$ anode, Alion batteries would theoretically be able to surpass the current performance of LIBs. LIBs have been widespread for several decades and a considerable amount of research as had them almost reach their maximum capacity. Since research into Al-ion batteries is in its infancy, there is still significant room for improvement, which leaves them as very promising candidates as alternatives to LIBs.

ii. Since the choice for a cathode material in Al-ion batteries is limited due to the strong bonding between $\mathrm{Al}^{3+}$ ions and host structure that results in slow diffusion kinetics, improvements in that regards can be achieved with cathode structures that have high porosity, large surface area and highly-active facets.

iii. For many cathode materials, there is a lack of data in terms of intercalation of multivalent ions $\left(\mathrm{Al}^{3+}\right)$ into the cathode crystal structure exist in state-of-the-art. For example, carbon, $\mathrm{TiO}_{2}, \mathrm{~V}_{2} \mathrm{O}_{5}$, prussian blue and sulfur based materials all have a lack of available data. In order to understand in details intercalation mechanism of different types of Al-ion batteries, more research work has to be conducted in the field.

iv. State-of-the-art of Al-ion batteries are very limited in terms of any discussion related to anode and electrolytes. In order to make improvements in all battery relevant metrics, this topic should also be addressed in future research of Al-ion batteries. 
v. Since the majority of cathode materials discussed in this review were initially used in $\mathrm{Li}$ and $\mathrm{Mg}$ based battery systems, this area of research could potentially provide new ideas for future generations of $\mathrm{Al}$ based batteries.

Received: ((will be filled in by the editorial staff)) Revised: ((will be filled in by the editorial staff)) Published online: ((will be filled in by the editorial staff))

\section{References}

[1] Y. Wang, G. Cao, Adv. Mater. 2008, 20, 2251-2269.

[2] H. Li, Z. Wang, L. Chen, X. Huang, Adv. Mater. 2009, 21, 4593-4607.

[3] L. Ji, Z. Lin, M. Alcoutlabi, X. Zhang, Energy Env. Sci 2011, 4, 2682-2699.

[4] S.-W. Kim, D.-H. Seo, X. Ma, G. Ceder, K. Kang, Adv. Energy Mater. 2012, 2, 710-721.

[5] V. Palomares, P. Serras, I. Villaluenga, K. B. Hueso, J. Carretero-González, T. Rojo, Energy Environ. Sci. 2012, 5, 5884-5901.

[6] P. Saha, M. K. Datta, O. I. Velikokhatnyi, A. Manivannan, D. Alman, P. N. Kumta, Prog. Mater. Sci. 2014, 66, 1-86.

[7] D. Aurbach, Z. Lu, A. Schechter, Y. Gofer, H. Gizbar, R. Turgeman, Y. Cohen, M. Moshkovich, E. Levi, Nature 2000, 407, 724-727.

[8] M.-C. Lin, M. Gong, B. Lu, Y. Wu, D.-Y. Wang, M. Guan, M. Angell, C. Chen, J. Yang, B.-J. Hwang, et al., Nature 2015, 520, 324-328.

[9] C. D. Wessells, R. A. Huggins, Y. Cui, Nat. Commun. 2011, 2, 550.

[10] A. Ponrouch, C. Frontera, F. Bardé, M. R. Palacín, Nat. Mater. 2016, 15, 169-172.

[11] N. Jayaprakash, S. K. Das, L. A. Archer, Chem. Commun. 2011, 47, 12610-12612.

[12] Q. Li, N. J. Bjerrum, J. Power Sources 2002, 110, 1-10.

[13] R. F. Hadley, Primary Cell Construction, Google Patents, 1951.

[14] G. W. Heise, E. A. Schumacher, Primary Cell or Battery, Google Patents, 1952.

[15] D. E. Sargent, Voltaic Cell, Google Patents, 1951.

[16] R. Samuel, Primary Cell, Google Patents, 1953.

[17] J. J. J. Stokes, Primary Cell Anode, Google Patents, 1957.

[18] J. J. J. Stokes, Primary Cell, Google Patents, 1958.

[19] J. J. J. Stokes, Primary Cell, Google Patents, 1967.

[20] H. Wang, Y. Bai, S. Chen, X. Luo, C. Wu, F. Wu, J. Lu, K. Amine, ACS Appl. Mater. Interfaces 2015, 7, 80-84.

[21] H. Sun, W. Wang, Z. Yu, Y. Yuan, S. Wang, S. Jiao, Chem. Commun. 2015, 51, 1189211895.

[22] J. V. Rani, V. Kanakaiah, T. Dadmal, M. S. Rao, S. Bhavanarushi, J. Electrochem. Soc. 2013, 160, A1781-A1784. 
[23] W. Wang, B. Jiang, W. Xiong, H. Sun, Z. Lin, L. Hu, J. Tu, J. Hou, H. Zhu, S. Jiao, Sci. Rep. 2013, 3, DOI 10.1038/srep03383.

[24] L. Geng, G. Lv, X. Xing, J. Guo, Chem. Mater. 2015, 27, 4926-4929.

[25] N. S. Hudak, J. Phys. Chem. C 2014, 118, 5203-5215.

[26] G. Cohn, L. Ma, L. A. Archer, J. Power Sources 2015, 283, 416-422.

[27] Y. Bai, Y. Cao, J. Zhang, M. Wang, R. Li, P. Wang, S. M. Zakeeruddin, M. Grätzel, Nat. Mater. 2008, 7, 626-630.

[28] S. Bai, C. Bu, Q. Tai, L. Liang, Y. Liu, S. You, Z. Yu, S. Guo, X. Zhao, ACS Appl. Mater. Interfaces 2013, 5, 3356-3361.

[29] T. J. Macdonald, Y. J. Mange, M. R. Dewi, H. ubayda Islam, I. P. Parkin, W. M. Skinner, T. Nann, J Mater Chem A 2015.

[30] T. J. Macdonald, D. D. Tune, M. R. Dewi, C. T. Gibson, J. G. Shapter, T. Nann, ChemSusChem 2015, 8, 3396-3400.

[31] P. Wang, S. M. Zakeeruddin, I. Exnar, M. Grätzel, Chem. Commun. 2002, 2972-2973.

[32] K. M. Son, M. G. Kang, R. Vittal, J. Lee, K.-J. Kim, J. Appl. Electrochem. 2008, 38, 16471652.

[33] S. Liu, J. J. Hu, N. F. Yan, G. L. Pan, G. R. Li, X. P. Gao, Energy Environ. Sci. 2012, 5, 9743-9746.

[34] J.-M. Tarascon, M. Armand, Nature 2001, 414, 359-367.

[35] C. D. Wessells, S. V. Peddada, R. A. Huggins, Y. Cui, Nano Lett. 2011, 11, 5421-5425.

[36] H. D. Yoo, I. Shterenberg, Y. Gofer, G. Gershinsky, N. Pour, D. Aurbach, Energy Environ. Sci. 2013, 6, 2265-2279.

[37] P. G. Bruce, B. Scrosati, J.-M. Tarascon, Angew. Chem. Int. Ed. 2008, 47, 2930-2946.

[38] M. D. Slater, D. Kim, E. Lee, C. S. Johnson, Adv. Funct. Mater. 2013, 23, 947-958.

[39] G. Y. Yang, L. Chen, P. Jiang, Z. Y. Guo, W. Wang, Z. P. Liu, RSC Adv. 2016, 6, 4765547660.

[40] R. Hagiwara, M. Lerner, N. Bartlett, T. Nakajima, J. Electrochem. Soc. 1988, 135, 23932394.

[41] R. Yazami, A. Hamwi, Solid State Ion. 1988, 28, 1756-1761.

[42] G. G. Amatucci, N. Pereira, J. Fluor. Chem. 2007, 128, 243-262.

[43] J. Giraudet, D. Claves, K. Guérin, M. Dubois, A. Houdayer, F. Masin, A. Hamwi, J. Power Sources 2007, 173, 592-598.

[44] X. Miao, J. Yang, W. Pan, H. Yuan, Y. Nuli, S. Hirano, Electrochimica Acta 2016, 210, 704-711.

[45] F. Giordano, A. Abate, J. P. Correa Baena, M. Saliba, T. Matsui, S. H. Im, S. M. Zakeeruddin, M. K. Nazeeruddin, A. Hagfeldt, M. Graetzel, Nat. Commun. 2016, 7, 10379.

[46] C. Sotelo-Vazquez, N. Noor, A. Kafizas, R. Quesada-Cabrera, D. O. Scanlon, A. Taylor, J. R. Durrant, I. P. Parkin, Chem. Mater. 2015, 27, 3234-3242.

[47] Y. Lu, S. Sathasivam, J. Song, C. R. Crick, C. J. Carmalt, I. P. Parkin, Science 2015, 347, 1132-1135.

[48] V. Gentili, S. Brutti, L. J. Hardwick, A. R. Armstrong, S. Panero, P. G. Bruce, Chem. Mater. 2012, 24, 4468-4476.

[49] A. R. Armstrong, G. Armstrong, J. Canales, R. García, P. G. Bruce, Adv. Mater. 2005, 17, 862-865.

[50] D. Deng, M. G. Kim, J. Y. Lee, J. Cho, Energy Environ. Sci. 2009, 2, 818-837.

[51] Y. Liu, S. Sang, Q. Wu, Z. Lu, K. Liu, H. Liu, Electrochimica Acta 2014, 143, 340-346.

[52] Y. J. He, J. F. Peng, W. Chu, Y. Z. Li, D. G. Tong, J. Mater. Chem. A 2014, 2, 1721-1731.

[53] Y. Yeo, J.-W. Jung, K. Park, I.-D. Kim, Sci. Rep. 2015, 5, 13862.

[54] M. Fehse, S. Cavaliere, P. E. Lippens, I. Savych, A. Iadecola, L. Monconduit, D. J. Jones, J. Rozière, F. Fischer, C. Tessier, et al., J. Phys. Chem. C 2013, 117, 13827-13835. 
[55] Y. Tang, Y. Zhang, J. Deng, J. Wei, H. L. Tam, B. K. Chandran, Z. Dong, Z. Chen, X. Chen, Adv. Mater. 2014, 26, 6111-6118.

[56] R. J. Cava, D. W. Murphy, S. Zahurak, A. Santoro, R. S. Roth, J. Solid State Chem. 1984, 53, 64-75.

[57] L. D. Reed, E. Menke, J. Electrochem. Soc. 2013, 160, A915-A917.

[58] T. Kudo, Y. Ikeda, T. Watanabe, M. Hibino, M. Miyayama, H. Abe, K. Kajita, Solid State Ion. 2002, 152-153, 833-841.

[59] E. Levi, Y. Gofer, D. Aurbach, Chem. Mater. 2010, 22, 860-868.

[60] H. Yamada, K. Tagawa, M. Komatsu, I. Moriguchi, T. Kudo, J. Phys. Chem. C 2007, 111, 8397-8402.

[61] M. Xie, X. Sun, H. Sun, T. Porcelli, S. M. George, Y. Zhou, J. Lian, J. Mater. Chem. A 2015, 4, 537-544.

[62] M. Chiku, H. Takeda, S. Matsumura, E. Higuchi, H. Inoue, ACS Appl. Mater. Interfaces 2015, 7, 24385-24389.

[63] S. T. Myung, K. Izumi, S. Komaba, Y. K. Sun, H. Yashiro, N. Kumagai, Chem. Mater. 2005, 17, 3695-3704.

[64] W. Li, J. R. Dahn, D. S. Wainwright, Science 1994, 264, 1115-1118.

[65] M. Winter, J. O. Besenhard, M. E. Spahr, P. Novák, Adv. Mater. 1998, 10, 725-763.

[66] L. J. Murray, M. Dincă, J. R. Long, Chem. Soc. Rev. 2009, 38, 1294-1314.

[67] S. Ferlay, T. Mallah, R. Ouahès, P. Veillet, M. Verdaguer, Nature 1995, 378, 701-703.

[68] J. Wang, Chem. Rev. 2008, 108, 814-825.

[69] Z. Li, K. Xiang, W. Xing, W. C. Carter, Y.-M. Chiang, Adv. Energy Mater. 2015, 5, n/an/a.

[70] S. Liu, G. L. Pan, G. R. Li, X. P. Gao, J. Mater. Chem. A 2014, 3, 959-962.

[71] L. D. Reed, S. N. Ortiz, M. Xiong, E. J. Menke, Chem. Commun. 2015, 51, 14397-14400.

[72] J. Muldoon, C. B. Bucur, T. Gregory, Chem. Rev. 2014, 114, 11683-11720.

[73] E. Markevich, V. Baranchugov, D. Aurbach, Electrochem. Commun. 2006, 8, 1331-1334.

[74] P. Saha, P. H. Jampani, M. K. Datta, D. Hong, C. U. Okoli, A. Manivannan, P. N. Kumta, J. Phys. Chem. C 2015, 119, 5771-5782.

[75] B. Lee, H. R. Lee, T. Yim, J. H. Kim, J. G. Lee, K. Y. Chung, B. W. Cho, S. H. Oh, J. Electrochem. Soc. 2016, 163, A1070-A1076.

[76] S.-I. Na, S.-S. Kim, J. Jo, D.-Y. Kim, Adv. Mater. 2008, 20, 4061-4067.

[77] S. W. Thomas, G. D. Joly, T. M. Swager, Chem. Rev. 2007, 107, 1339-1386.

[78] R. H. Friend, R. W. Gymer, A. B. Holmes, J. H. Burroughes, R. N. Marks, C. Taliani, D. D. C. Bradley, D. A. D. Santos, J. L. Brédas, M. Lögdlund, et al., Nature 1999, 397, 121128.

[79] P. Simon, Y. Gogotsi, Nat. Mater. 2008, 7, 845-854.

[80] Y.-X. Yin, S. Xin, Y.-G. Guo, L.-J. Wan, Angew. Chem. Int. Ed. 2013, 52, 13186-13200.

[81] X. Ji, S. Evers, R. Black, L. F. Nazar, Nat. Commun. 2011, 2, 325.

[82] Y.-S. Su, Y. Fu, T. Cochell, A. Manthiram, Nat. Commun. 2013, 4, 2985.

[83] S. Xin, Y.-X. Yin, Y.-G. Guo, L.-J. Wan, Adv. Mater. 2014, 26, 1261-1265.

[84] X. Lu, M. E. Bowden, V. L. Sprenkle, J. Liu, Adv. Mater. 2015, 27, 5915-5922.

[85] S. Licht, J. Hwang, T. S. Light, R. Dillon, J. Electrochem. Soc. 1997, 144, 948-955.

[86] D. Peramunage, R. Dillon, S. Licht, J. Power Sources 1993, 45, 311-323.

[87] P. G. Bruce, L. J. Hardwick, K. m. Abraham, MRS Bull. 2011, 36, 506-512.

[88] J. Liu, Y. Wen, Y. Wang, P. A. van Aken, J. Maier, Y. Yu, Adv. Mater. 2014, 26, 60256030.

[89] L. Li, M. Cabán-Acevedo, S. N. Girard, S. Jin, Nanoscale 2014, 6, 2112-2118.

[90] Z. Hu, Z. Zhu, F. Cheng, K. Zhang, J. Wang, C. Chen, J. Chen, Energy Environ. Sci. 2015, 8, 1309-1316.

[91] N. Koura, T. Yui, S. Takahashi, J. Jpn. Inst. Light Met. 1985, 35, 203-208. 


\section{WILEY-VCH}

[92] T. Mori, Y. Orikasa, K. Nakanishi, C. Kezheng, M. Hattori, T. Ohta, Y. Uchimoto, J. Power Sources 2016, 313, 9-14.

[93] B. Kang, G. Ceder, Nature 2009, 458, 190-193.

[94] X.-G. Sun, Z. Bi, H. Liu, Y. Fang, C. A. Bridges, M. P. Paranthaman, S. Dai, G. M. Brown, Chem. Commun. 2016, 52, 1713-1716.

[95] P. R. Gifford, J. B. Palmisano, J. Electrochem. Soc. 1988, 135, 650-654.

[96] E. Wiberg, N. Wiberg, Inorganic Chemistry, Academic Press, 2001.

[97] W. J. Rankin, Minerals, Metals and Sustainability: Meeting Future Material Needs, CRC Press, Boca Raton, Fla., 2011.

[98] B. Sahoo, N. Charan, samantaray Asutosh, P. Kumar, Inorganic Chemistry, PHI Learning, 2012.

[99] J. Emsley, Nature's Building Blocks: An A-Z Guide to the Elements, OUP Oxford, 2011. 


\section{WILEY-VCH}

Tables \& Figures

Table 1. Theoretical key performance indicators of different metal anodes for batteries.

\begin{tabular}{|c|c|c|c|c|c|c|}
\hline & $\mathbf{L i}$ & $\mathrm{Na}$ & $\mathbf{M g}$ & Al & $\mathbf{K}$ & $\mathrm{Ca}$ \\
\hline Valence & + & + & $2+$ & $3+$ & + & $2+$ \\
\hline Atomic weight & 6.94 & 22.99 & 24.31 & 26.98 & 39.10 & 40.08 \\
\hline Sp. Capacity [Ah/kg] & 3862 & 1166 & 2205 & 2980 & 685 & 1340 \\
\hline Sp. Capacity [Ah/l] & 2062 & 1128 & 3832 & 8046 & 591 & 2060 \\
\hline Stand. Potential [V] ${ }^{[96]}$ & -3.04 & -2.71 & -2.36 & -1.68 & -2.93 & -2.87 \\
\hline Abundance $[p p m]^{[97-99]}$ & 18 & 22,700 & 23,000 & 82,000 & 18,400 & 41,000 \\
\hline
\end{tabular}

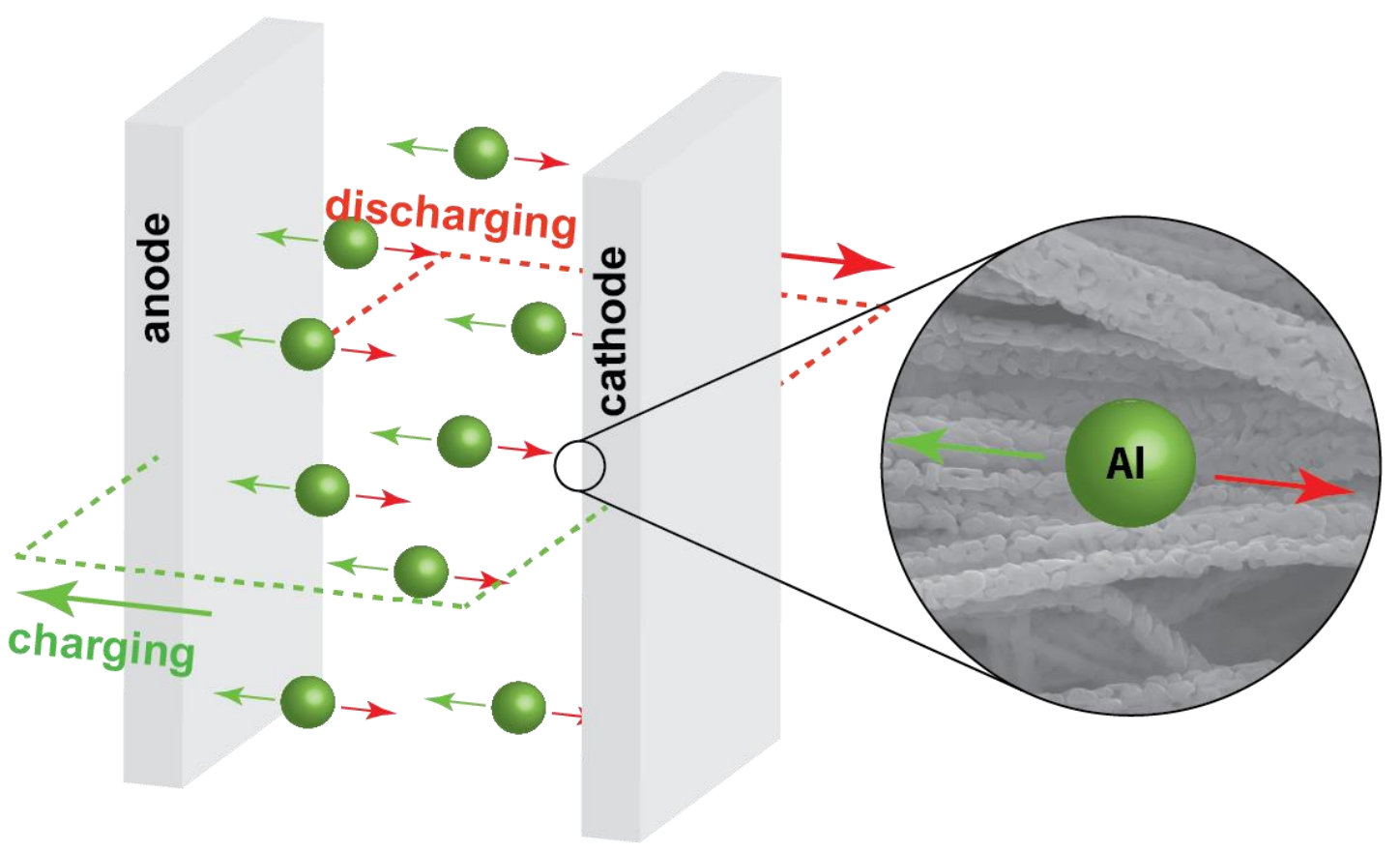

Figure 1. Schematic illustration of two-electrode cell configuration. 


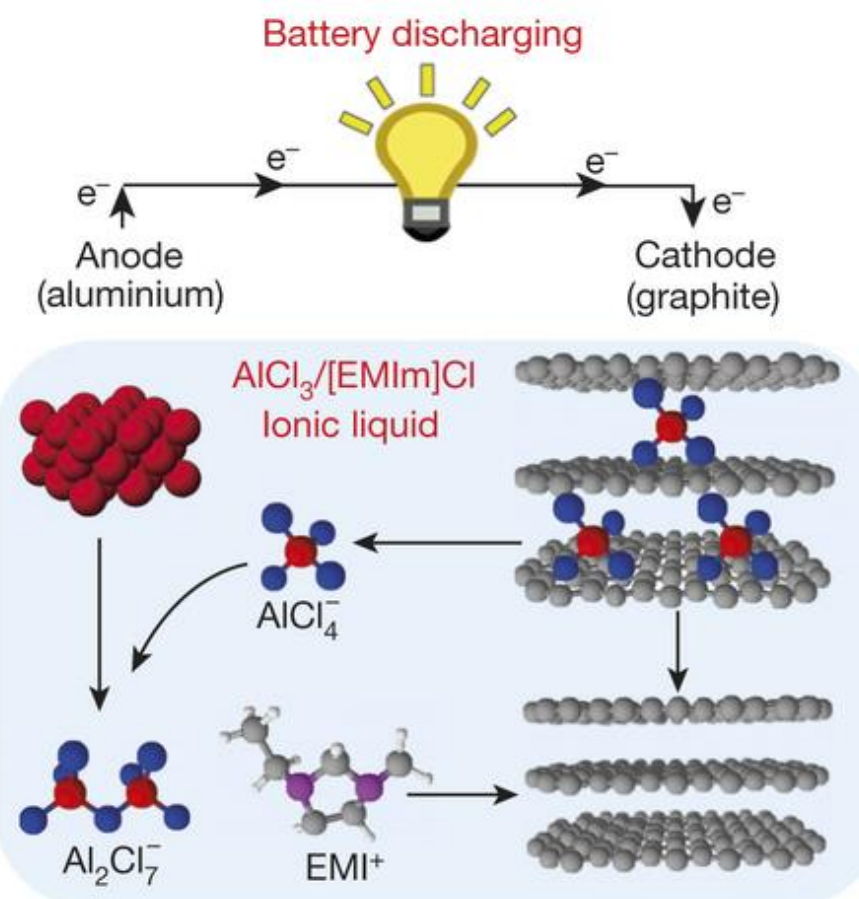

Figure 2. A schematic operation scheme of the Al/PG battery cell.

Reproduced with permission. ${ }^{[8]}$ Copyright 2015, Nature Publishing Group.

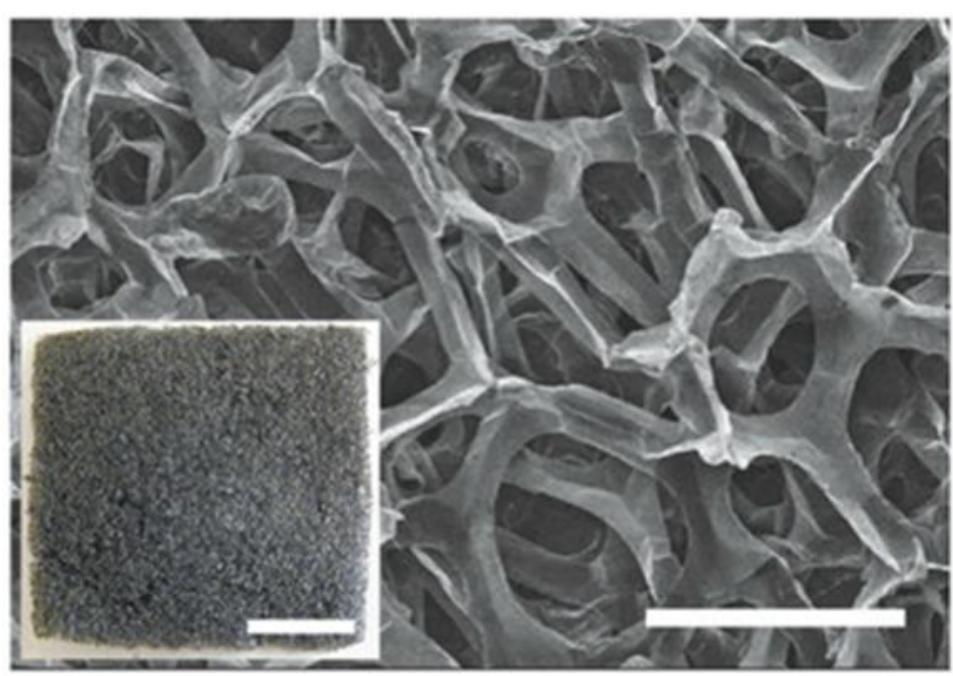

Figure 3. An SEM image of graphitic foam, scale bar $300 \mu \mathrm{m}$. Inset image, scale bar $1 \mathrm{~cm}$. Reproduced with permission. ${ }^{[8]}$ Copyright 2015, Nature Publishing Group. 


\section{WILEY-VCH}

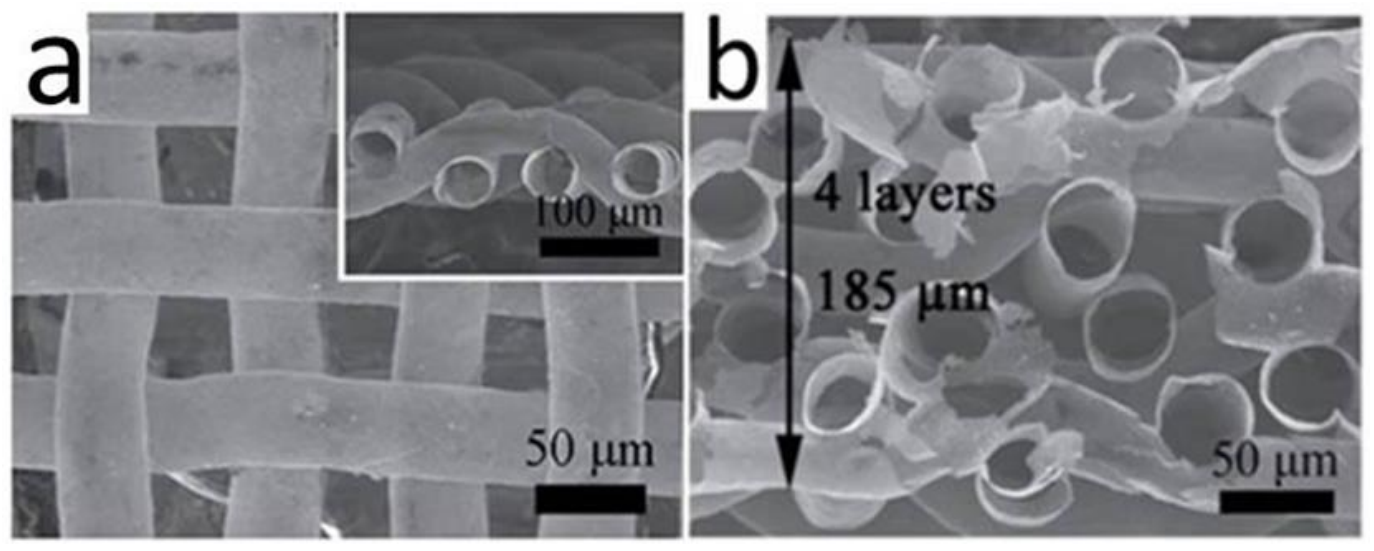

Figure 4. a) an SEM image of GMN; b) cross-sectional view of folded GMN. Reproduced with permission. ${ }^{[39]}$ Copyright 2016, RSC.

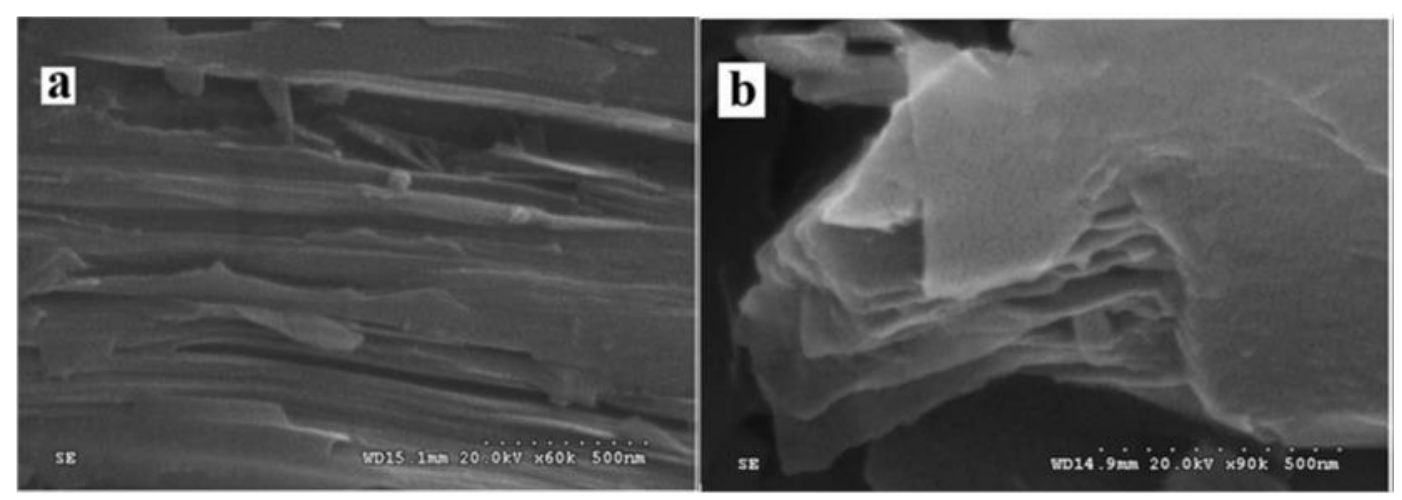

Figure 5. a) an SEM image of non-fluorinated graphite; b) fluorinated graphite cathode. Reproduced with permission. ${ }^{[22]}$ Copyright 2013, The Electrochemical Society. 


\section{WILEY-VCH}

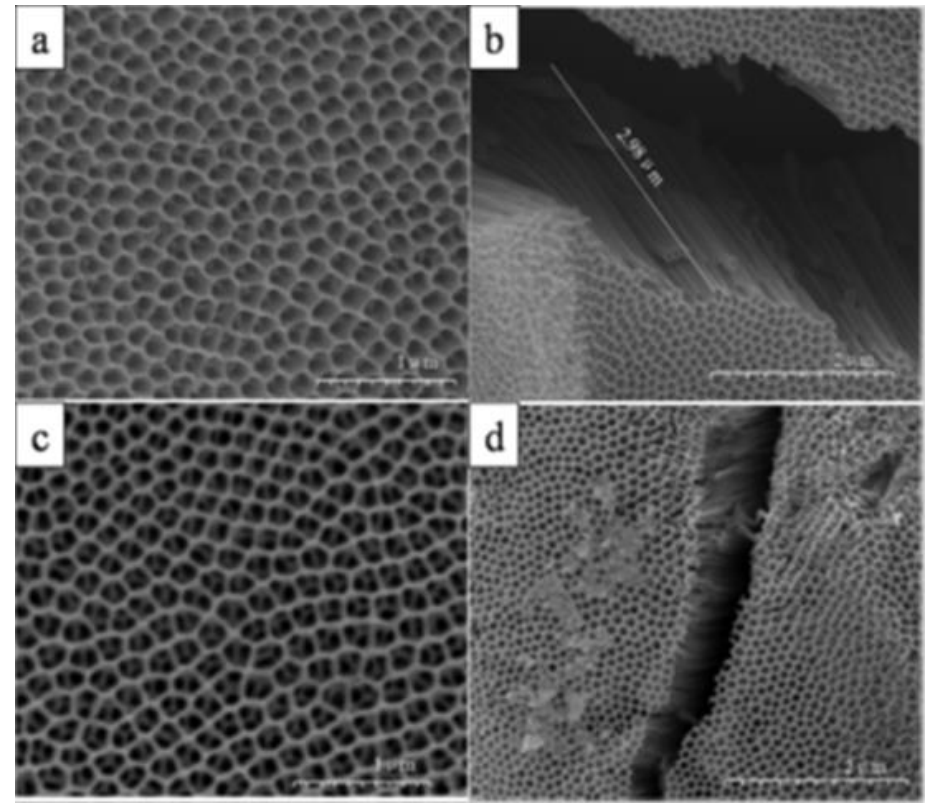

Figure 6. Field emission-SEM images (top and side view) of $\mathrm{TiO}_{2}-\mathrm{NTAs}$, before $(\mathrm{a}, \mathrm{b})$ and after $(\mathrm{c}, \mathrm{d})$ ion insertion.

Reproduced with permission. ${ }^{[51]}$ Copyright 2014, Elsevier.

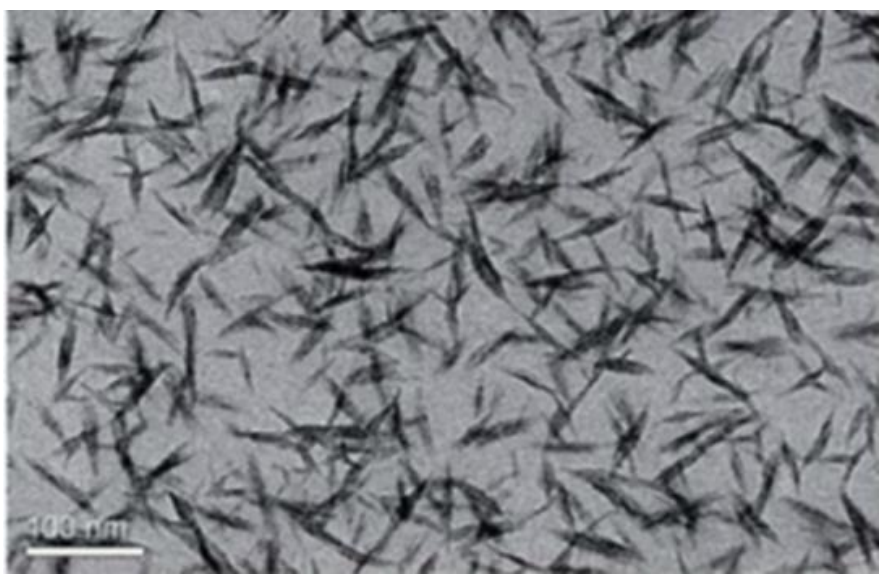

Figure 7. A TEM image of $\mathrm{TiO}_{2}$ nanoparticles prepared via SPP method. Reproduced with permission. ${ }^{[52]}$ Copyright 2014, RSC. 


\section{WILEY-VCH}

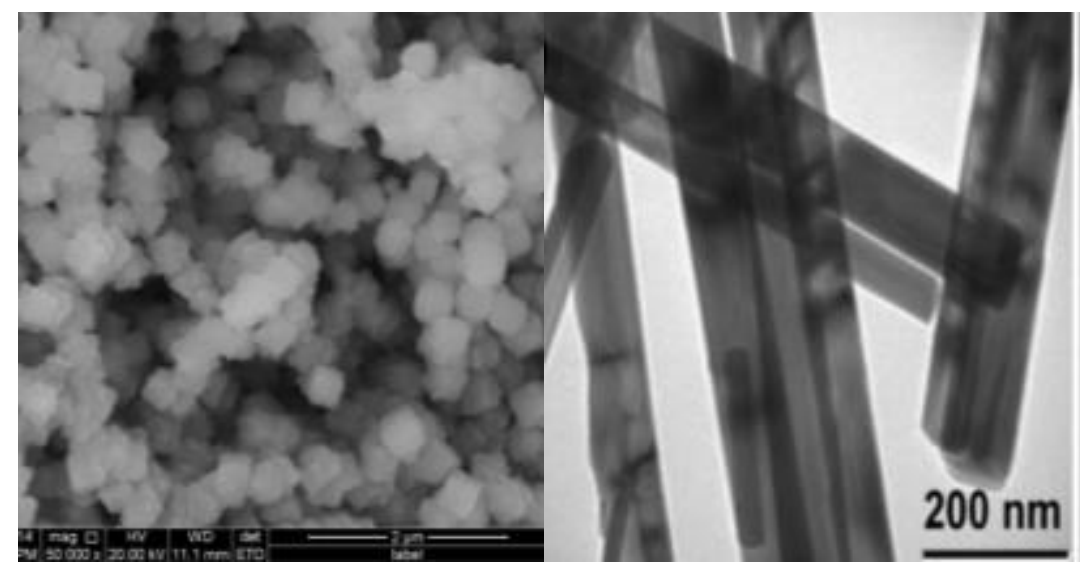

Figure 8. a) An SEM image of binder-free $\mathrm{Ni}-\mathrm{V}_{2} \mathrm{O}_{5}$; b) A TEM image of $\mathrm{V}_{2} \mathrm{O}_{5}$ nanowires. Reproduced with permission. ${ }^{[11,20]}$ Copyright 2011 \& 2015, RSC \& ACS.

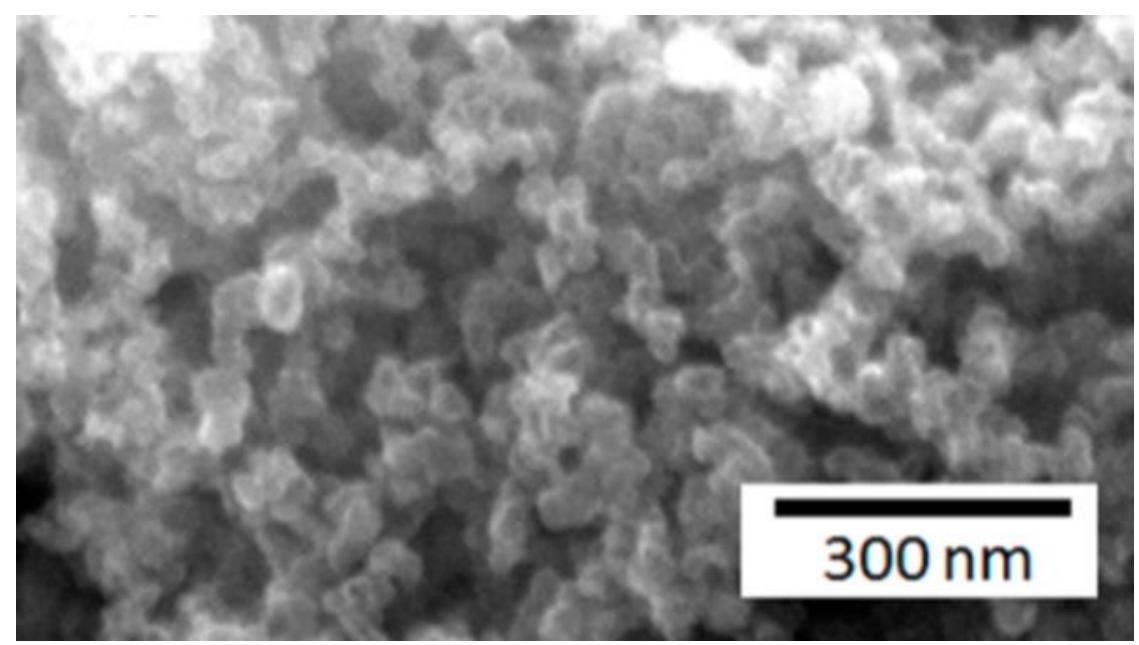

Figure 9. An SEM image of $\mathrm{V}_{2} \mathrm{O}_{5} / \mathrm{C}$ electrode.

Reproduced with permission. ${ }^{[62]}$ Copyright 2015, ACS. 


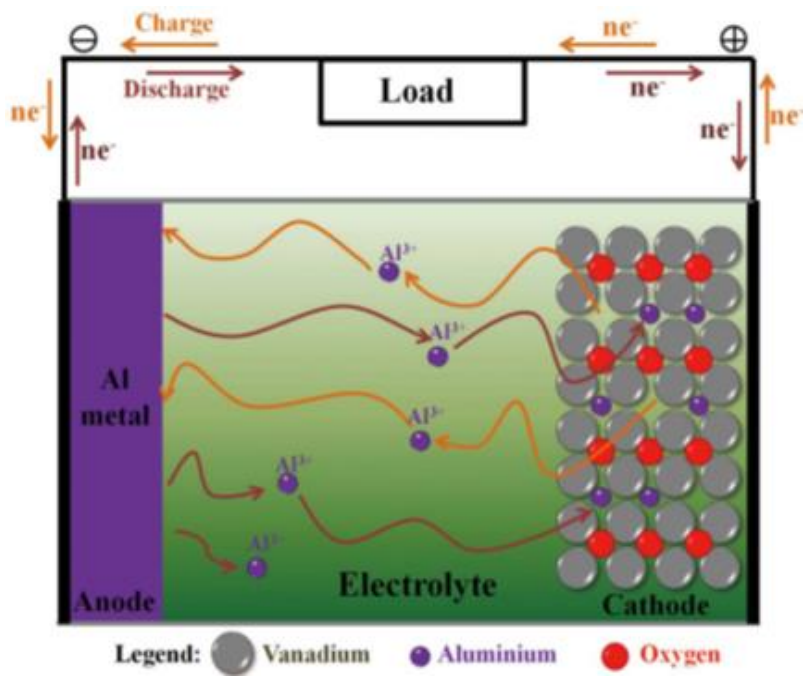

Figure 10. Process of $\mathrm{Al}^{3+}$ insertion/extraction.

Reproduced with permission. ${ }^{[23]}$ Copyright 2013, Nature Publishing Group.

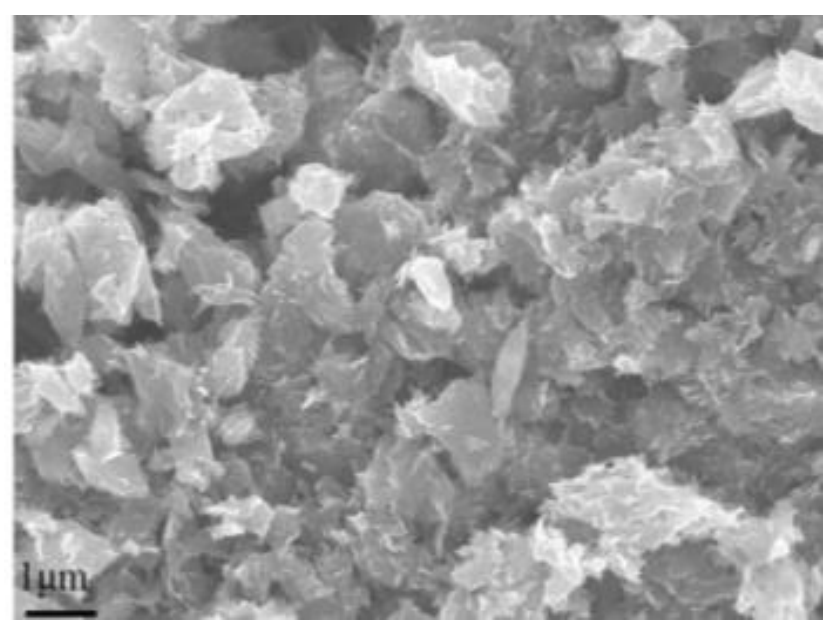

Figure 11. A field emission-SEM image of $\mathrm{VO}_{2}$ cathode.

Reproduced with permission. ${ }^{[23]}$ Copyright 2013, Nature Publishing Group. 


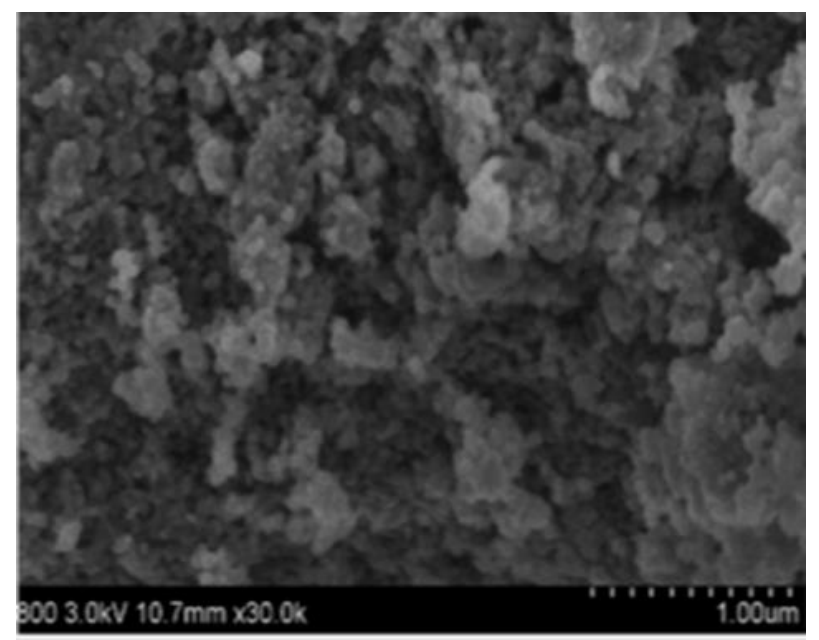

Figure 12. An SEM image of CuHCF material.

Reproduced with permission. ${ }^{[70]}$ Copyright 2014, RSC.

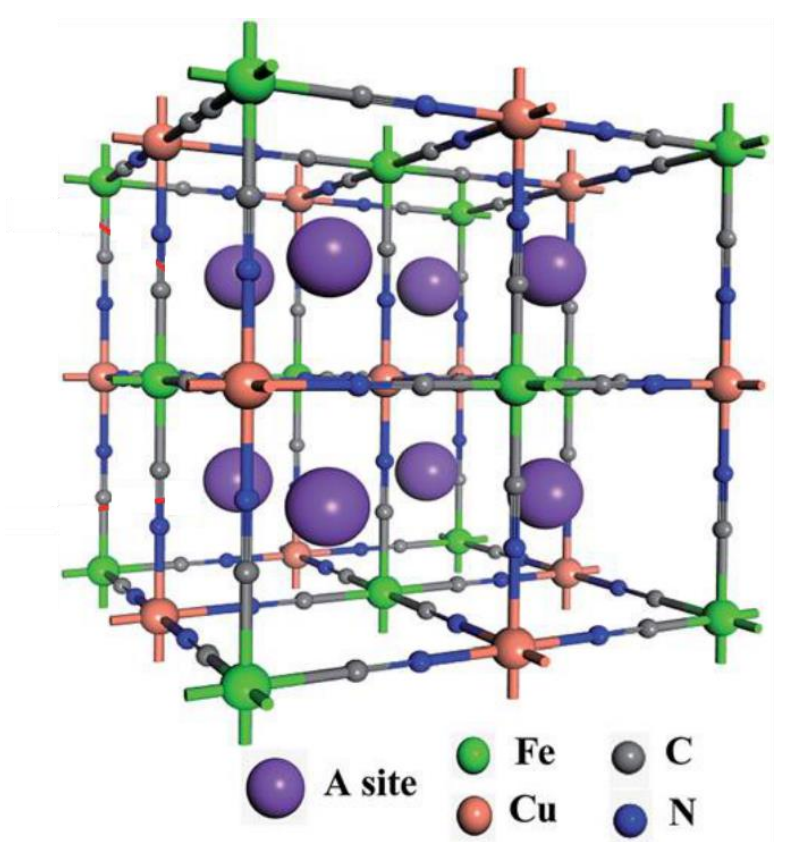

Figure 13. A cubic unit cell of CuHCF.

Reproduced with permission. ${ }^{[71]}$ Copyright 2015, RSC. 


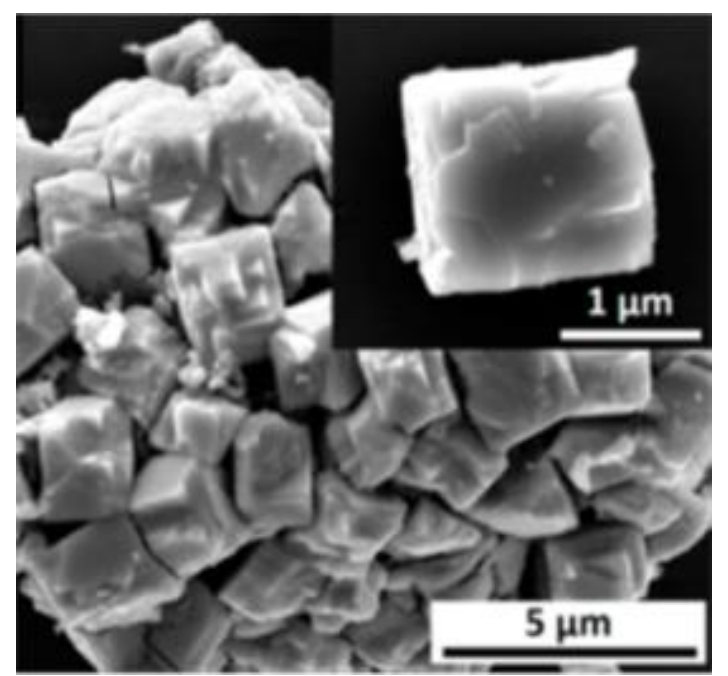

Figure 14. An SEM image of $\mathrm{Mo}_{6} \mathrm{~S}_{8}$ cathode.

Reproduced with permission. ${ }^{[24]}$ Copyright 2015, ACS.

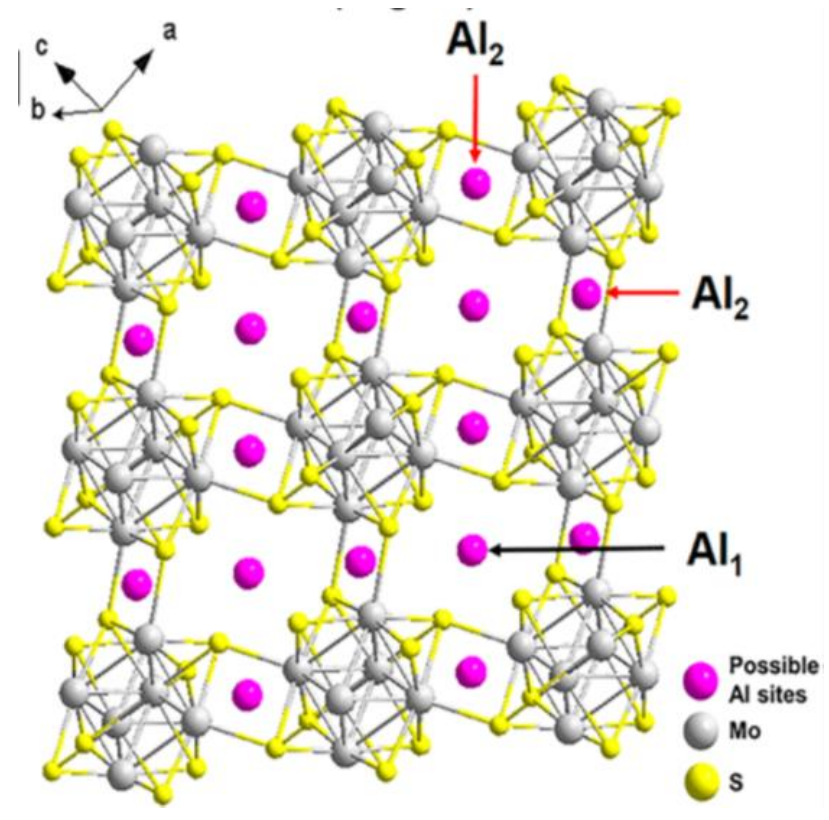

Figure 15. Crystal structure of $\mathrm{Mo}_{6} \mathrm{~S}_{8}$ with intercalated Al. ${ }^{[24]}$ Copyright 2015, ACS. 


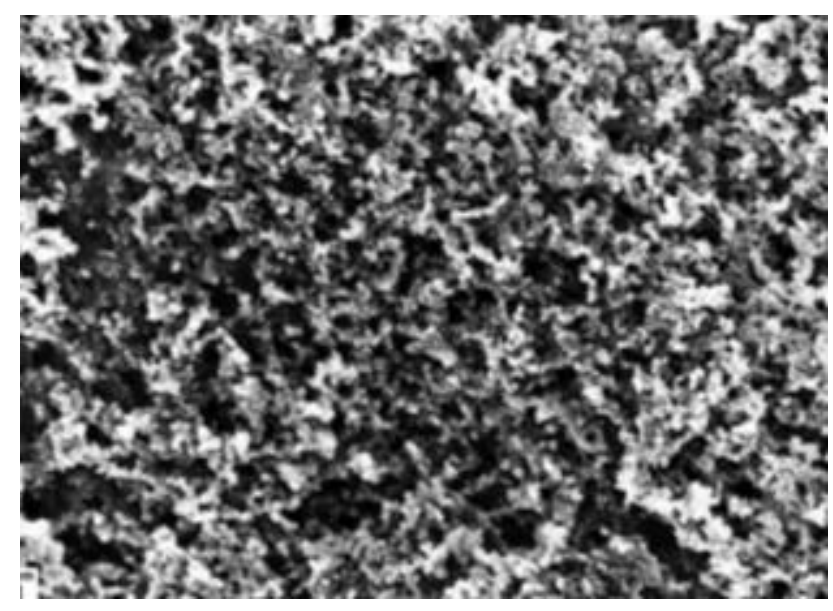

Figure 16. An SEM image of the sulfur cathode.

Reproduced with permission. ${ }^{[26]}$ Copyright 2015, Elsevier.

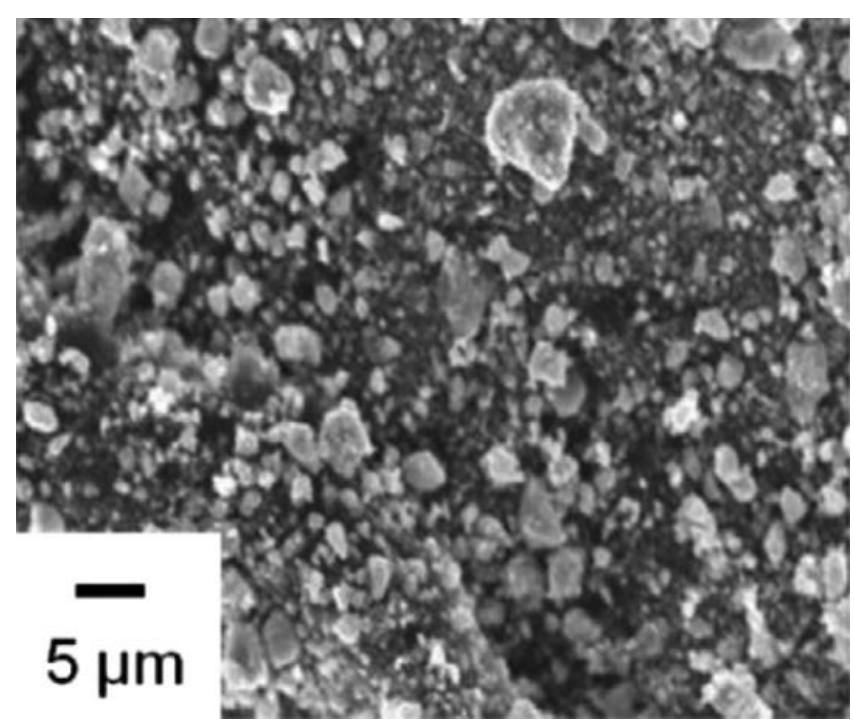

Figure 17. An SEM image of the $\mathrm{FeS}_{2}$ particles.

Reproduced with permission. ${ }^{[92]}$ Copyright 2016, Elsevier. 


\section{WILEY-VCH}

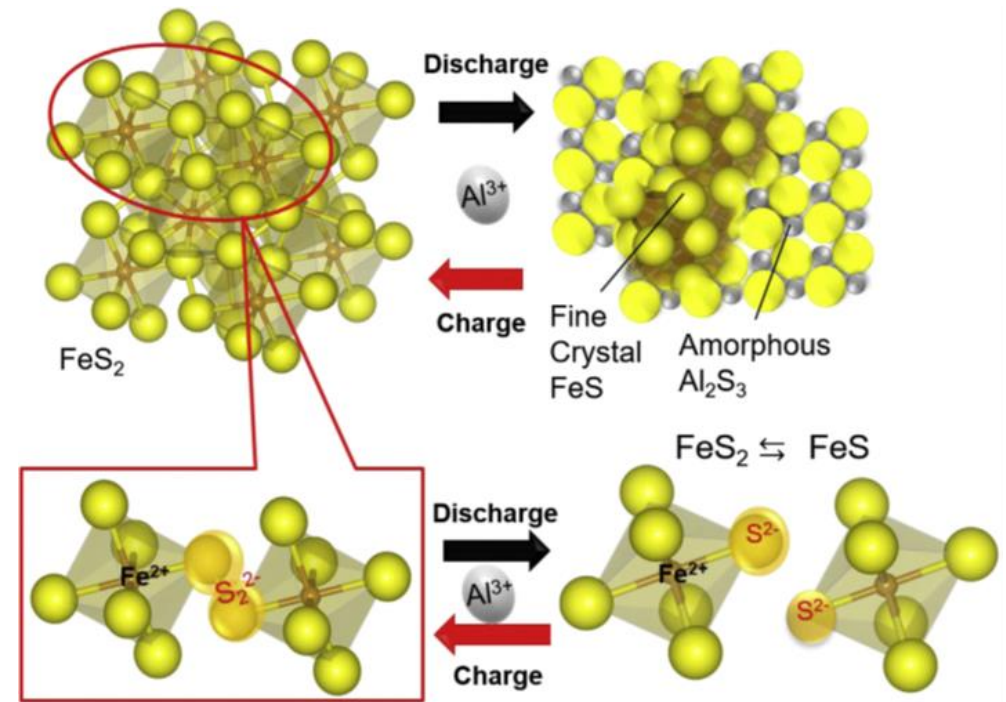

Figure 18. Reaction model of $\mathrm{FeS}_{2}$ with intercalated $\mathrm{Al}^{3+}$ ions. ${ }^{[92]}$ Copyright 2016, Elsevier.

((For Essays, Feature Articles, Progress Reports, and Reviews, please insert up to three author biographies and photographs here, max. 100 words each))

Author Photograph(s) ((40 mm broad, $50 \mathrm{~mm}$ high, gray scale)) 


\section{WILEY-VCH}

Is there a life after lithium? The most promising alternative to lithium-ion batteries is aluminium. However, the current performance of aluminium-ion batteries is not suitable for large scale application yet. This review article provides a critical overview of the current stateor-the-art in aluminium-ion batteries.

\section{Aluminium ion batteries}

F. Ambroz, T. J. Macdonald, T. Nann*

Trends in aluminium-based intercalation batteries

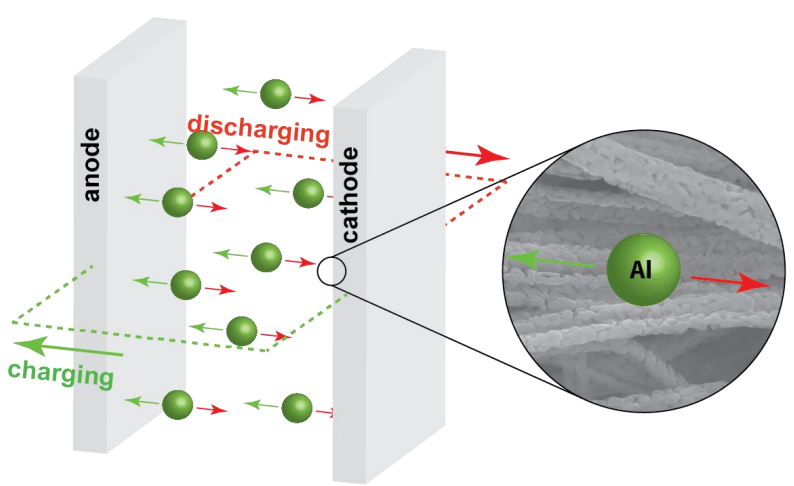

